Research Article

\title{
Arch Antislide Pile-Wall Structure System: Model and Optimization
}

\author{
Heng Li, ${ }^{1}$ Hui Wang, ${ }^{2}$ Gaowei Yue $\mathbb{D D}^{2}{ }^{2}$ Fasuo Zhao, ${ }^{1}$ and Wenzhe $\mathrm{Li}^{1}$ \\ ${ }^{1}$ School of Engineering and Surveying, Chang'an University, Xi'an 710054, China \\ ${ }^{2}$ School of Civil Engineering, Henan Polytechnic University, Jiaozuo, Henan 454000, China \\ Correspondence should be addressed to Gaowei Yue; mxlygw@126.com
}

Received 7 August 2020; Revised 18 January 2021; Accepted 25 January 2021; Published 9 February 2021

Academic Editor: Mijia Yang

Copyright (ㅇ 2021 Heng Li et al. This is an open access article distributed under the Creative Commons Attribution License, which permits unrestricted use, distribution, and reproduction in any medium, provided the original work is properly cited.

For the problems of unreasonable force and large deformation of traditional antislide structure system, three new arch antislide pilewall structure systems are designed for a loess landslide treatment project in Northern Shanxi province. The working performances of four kinds of antislide structures are numerically simulated and analyzed to realize the optimization of the antislide structure system. The results show that the arch antislide pile-wall structure system is a rigid connection between the piles and cap beam, and the antislide pile, cap beam, and sliding bed soil form a spatial nearly rigid structure. Cap beam can better transfer the bending moment generated by the larger thrust in the landslide middle to the piles with less force on both sides of the landslide, so that the stress and deformation of the whole antislide system tend to be uniform, which makes the antislide system "joint operation." And this structural form increases the overall stiffness and bending capacity and reduces the possibility that the middle pile is destroyed first and loses its working capacity due to large thrust. Compared with the traditional antislide structure system (Model-1), the average displacement of the pile head is reduced by about $60 \%$, and the total control bending moment of the system is reduced by about $6 \%$. The purpose of Model-3 and Model-4 (anchorage arch antislide pile-wall structure system and pull-rod arch antislide pile-wall structure system) is to restrict the deformation of cap beam in both positive and negative directions of $x$-axis in arch antislide pile-wall structure system, which plays a certain role in coordinating the deformation of antislide structure and better coordinating the stress of each pile. The arch antislide pile-wall structure system (Model-2), anchorage arch antislide pile-wall structure system (Model-3), and pull-rod arch antislide pile-wall structure system (Model-4) can better adapt and adjust the unbalanced thrust between the landslide piles; therefore, they have higher structural robustness than that of traditional antislide structure system. When achieving the management target with a 95\% structural reliability probability of the same landslide, the structural robust degrees of Model-1, Model-2, and Model-4 are $0.58,0.76$, and 0.81 , respectively. Therefore, the pull-rod arch antislide pile-wall structure system (Model-4) has the best performance among the other antislide structures. These studies lay a foundation for the engineering structural optimization of arch antislide pilewall structure system.

\section{Introduction}

Landslide refers to the phenomenon of slope movement with a large horizontal displacement component attached to its own weak structural plane $[1,2]$. When the landslide threatens the established project or human production and life, the appropriate measures should be taken to treat the landslide $[3,4]$. With the rapid development of urban construction, transportation, mining, environmental protection, and other industries, landslide treatment has become an increasingly important project [5-9].
Generally, landslide treatment includes biological treatment measures, drainage measures, slope cutting presser foot measures, and structure supporting measures $[10,11]$. In terms of structural support, the reinforced concrete antislide pile has been widely used with many advantages of strong antislide force, flexible pile position, small disturbance to landslide stability and geological environment, multiple piles constructed at the same time, and safe and fast construction. Therefore, it has become the main method for landslide geological disasters, especially for large-scale landslide treatment $[8,12,13]$. Matsii et al. 
$[14,15]$ proposed a computational scheme for soil and the pile interaction of single and two-row supporting structures and analyzed the stress-strain state (SSS) of soil and the pile interaction of two-row supporting structure. Zhang and Tan [16] and Shooshpasha and Amirdehi [17] studied the stability analysis of reinforced with one row of free head piles by shear strength reduction method and also analyzed the effects of pile location, pile length, pile spacing, pile bending stiffness, and slope angle on the performance of reinforced slope. Li et al. [18] and $\mathrm{Wu}$ et al. [19] presented a novel analytical solution to determine an optimal isosceles trapezoid cross section of stabilizing piles subjected to the lateral load. Yang et al. [20] and Zhang et al. [21] performed a series of laboratory model tests on the pile-reinforced slopes under horizontal and vertical loading conditions to investigate the pile reinforcement mechanism. Li et al. [22] adopted a simplified analytical model to analyze double-row pile stabilized slopes. Moreover, a framework is developed for analyzing the optimal locations of multirow piles considering multistage potential slip surfaces. Zhou et al. [23] established a physical model to study the phenomenon of the soil in front of piles gradually separated from piles as piles deformed elastically under reservoir operation, which can further understand the pile-soil interaction. Liu et al. [24] established a qualitative relationship between stress state and deformation and thermal infrared temperature from experiments to study the deformation and failure mechanism of a landslide stabilized with piles. Xue et al. [25] established a 3D finite element model (FEM) of the test to study the stability failure mechanism of PWFSs (pile-wall frame structures), which evaluated the effects of framework width, pile spacing, pile length, and diameter on structural stability. As the application of micropiles being extended from foundation engineering to landslide engineering, Wang and Yin [26], Ma et al. [27], and Li et al. [28] focused on studying the effects and failure mode of micropile in landslide reinforcement.

The above beneficial explorations in the structural form of antislide piles open up new ideas to optimize antislide structure system in space. However, the interaction between the piles is not considered; the pile location is still in plane or sectional plane layout. In essence, this optimization is carried out in isolation from the perspective of single pile. From the failure forms of some antislide pile structures, the main manifestations are shear failure of the top beam of the antislide pile, the bending failure of the antislide pile itself, and the overall instability of the structure system due to the insufficient bending stiffness [29]. In fact, all piles in the same landslide should be studied as a whole. Therefore, the antislide structure should have certain adaptability to the above uncertainties of landslide, or they should be a system, which can transfer the larger thrust on some piles to the other antislide piles with a relatively small force, so as to improve the reliability of the whole antislide structure.

In this paper, taking a loess landslide treatment project in Northern Shanxi province as an example, three new arch antislide pile-wall structure system models are numerically simulated and analyzed to compare their working performances with traditional antislide structure system model including the tress, deformation, and failure characteristics. At the same time, the concept of structural robustness is put forward to evaluate four kinds of antislide structural systems. Thus, it lays a foundation for further research and engineering structure optimization of arch antislide pile-wall structure system.

\section{Landslide Prototype and Antislide Structure System Design}

2.1. Reconstruction of Prototype Landslide. The prototype landslide is an ancient loess landslide in Northern Shanxi province, and the width and length of the tongue type landslide are about $120 \mathrm{~m}$ and $200 \mathrm{~m}$, respectively. There are two erosion gullies on both sides, as shown in Figure 1. Table 1 shows the physical and mechanical property indexes of each constituent element of landslide according to the geological exploration analysis.

The slope will be converted into a two-stage platform as an oil transportation station, and the platform elevation is $1282.00 \mathrm{~m}$ and $1260.00 \mathrm{~m}$, respectively, as shown in Figure 1. After the reconstruction, the slope of $1282.00 \mathrm{~m}$ elevation platform is in the limit stability state, and two storage tanks with a diameter of $20 \mathrm{~m}$ a height of $18 \mathrm{~m}$ are arranged on this platform. Each tank capacity of $5000 \mathrm{t}$ is designed on the expanded reinforced concrete substrate, the size of which is $52 \mathrm{~m}$ (length), $22 \mathrm{~m}$ (width), and $1.2 \mathrm{~m}$ (thickness). After oil storage tanks are filled, the rear edge slope will be unstable.

2.2. Model Design of Antislide Structure. For traditional antislide structure, the force of the structure is uneven and unreasonable. Therefore, the arch antislide pile-wall structure system, which is composed of the antislide piles and cap beam on the top, is designed to transfer the larger thrust in the landslide middle to the antislide piles on both sides of the landslide through cap beam. The purpose of this spatial arch structure is to give full play to the advantages of high compressive strength of cap beam concrete structure and the restraint capacity of spatial structure to deformation.

According to the basic requirements of ensuring slope safety and controlling slope deformation, the landslide is treated by arch antislide structure system with a rise-span ratio of $1: 10$ in the platform leading edge. Four kinds of arch antislide structure system are designed. And each physical model is established to numerically simulate and analyze the working performance, so as to find out the optimal arch antislide structure system.

2.2.1. Model-1: Traditional Antislide Structure. This structure is composed of 11 antislide piles which are arched arrangement at platform leading edge as shown in Figure 2(a). The size of the antislide pile is $2.00 \mathrm{~m}$ (with), $3.00 \mathrm{~m}$ (height), and $21.00 \mathrm{~m}$ (length), where the embedded section length is $9.00 \mathrm{~m}$ and the horizontal distance of the antislide pile center is $7.50 \mathrm{~m}$.

2.2.2. Model-2: Arch Antislide Pile-Wall Structure System. The size design of the pile structure is the same as Model1. The pile top is a rectangular cap beam with a sectional 


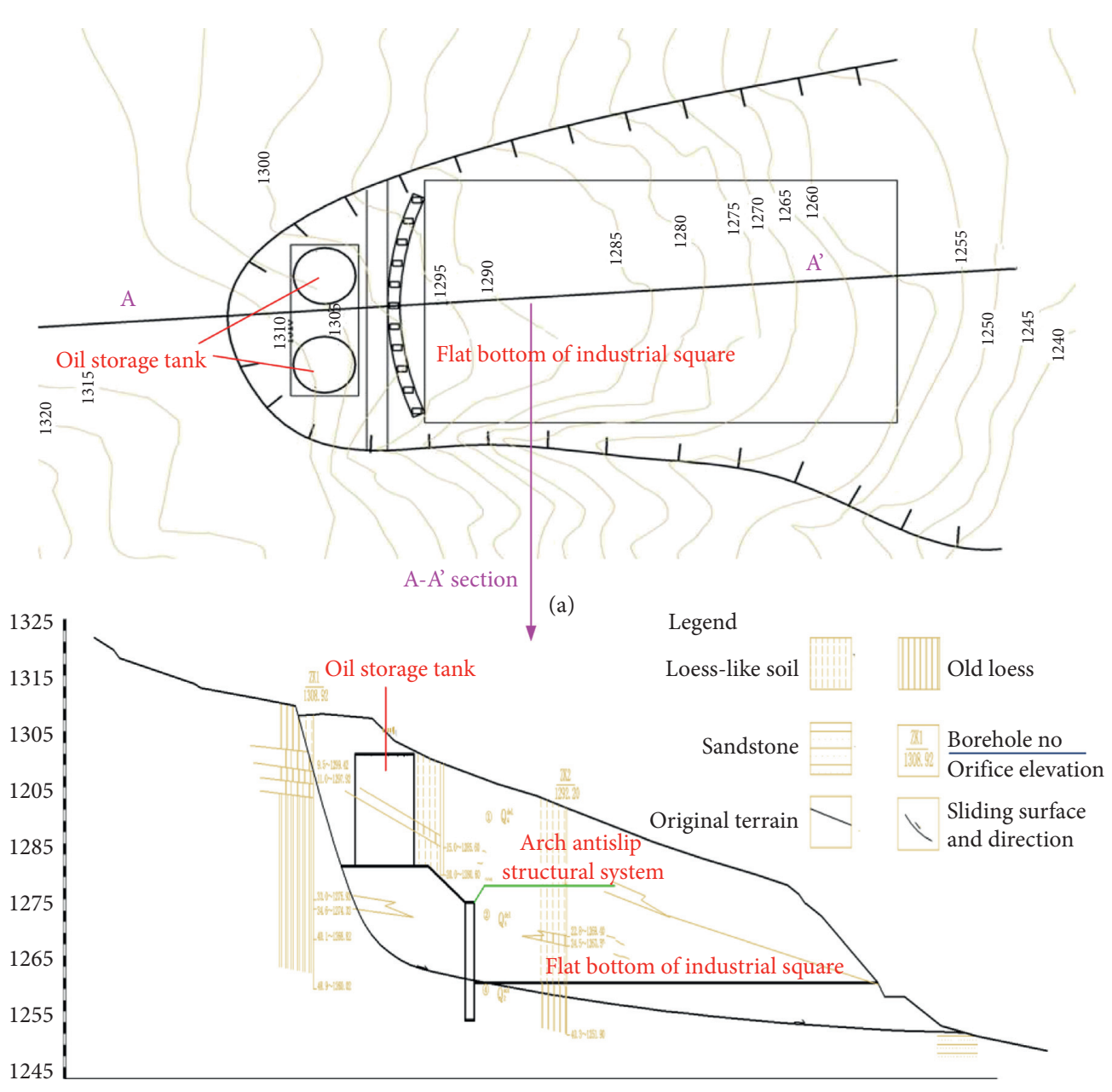

(b)

FIgUre 1: Schematic diagram of prototype landslide. (a) Plane engineering layout. (b) Cross-section engineering layout.

TABLE 1: Characteristics of landslide elements.

\begin{tabular}{|c|c|c|c|c|c|}
\hline \multirow{2}{*}{\multicolumn{2}{|c|}{ Category/location }} & \multirow{2}{*}{ Lithologic characters } & \multirow{2}{*}{$\begin{array}{c}\text { Bulk density } \\
\gamma\left(\mathrm{kN} / \mathrm{m}^{3}\right)\end{array}$} & \multicolumn{2}{|c|}{ Strength } \\
\hline & & & & $C(\mathrm{kPa})$ & $\varphi\left({ }^{\circ}\right)$ \\
\hline Sliding body & & Loessial soil & 17.94 & 32 & 23 \\
\hline \multirow{3}{*}{ Sliding belt } & Back & Plastic soft plastic loess & - & 6.7 & 15 \\
\hline & Middle & Plastic loess & - & 8.0 & 16 \\
\hline & Front & Gravel soil & - & 8.0 & 6.7 \\
\hline \multirow{3}{*}{ Sliding bed } & Back & Old loess & 20.1 & 96 & 24 \\
\hline & Middle & Old loess & 20.1 & 96 & 24 \\
\hline & Front & Sandstone (with mudstone) & 22 & 280 & 42 \\
\hline
\end{tabular}

size of $3.00 \mathrm{~m} \times 4.00 \mathrm{~m}$. And cap beam and the piles are rigidly connected as shown in Figure 2(b).

\subsubsection{Model-3: Anchorage Arch Antislide Pile-Wall Structure} System. The pile location, pile, and cap beam section dimensions are the same as Model-2. However, piles P1 and P11 were enlarged into anchorage, and the sectional area was enlarged to $3.00 \mathrm{~m} \times 4.00 \mathrm{~m}$ as shown in Figure 2(c).
2.2.4. Model-4: Pull-Rod Arch Antislide Pile-Wall Structure System. The pile location, pile, and cap beam section dimensions are the same as Model-2. However, a pull rod made of 1320 grade steel strand of 24 bunches is set on cap beam corresponding to piles $\mathrm{P} 1$ and $\mathrm{P} 11$ as shown in Figure 2(d). The cross-sectional area of steel strand is $1.6 \times 10^{4} \mathrm{~mm}^{2}$, and its tensile strength and elastic modulus are $1320 \mathrm{MPa}$ and $195 \mathrm{GPa}$, respectively.

The concrete strength grade of antislide pile and cap beam is C30, of which elastic modulus and compressive 
strength are $30 \mathrm{GPa}$ and 14.3 MPa. The longitudinal tensile reinforcement of antislide pile is $60 \mathrm{E} 32 \mathrm{~mm}$ with tensile strength $360 \mathrm{MPa}$, which is arranged in two rows of the pile, and the action point of the longitudinal reinforcement is $200 \mathrm{~m}$ away from the pile side; the longitudinal reinforcement of the pile body away from the mountainside is arranged according to the structure, and the pile control bending moment $M u=43434 \mathrm{kN}$.m. Both sides of cap beam are symmetrically reinforced, and each side has 90 HRB400 bars with a diameter of $32 \mathrm{~mm}$.

Notes. (1) The models are symmetric structure. (2) Unit is m. (3) The pile numbers are P1, P2, P3...P10, and P11, respectively from left to right. (4) Central coordinates of piles $\mathrm{P} 1 \sim \mathrm{P} 6$ are $(0,0),(7.5,2.73),(15,4.85),(22.5,6.32),(30,7.2)$, and $(37.5,7.5)$.

The antislide structure systems in Model-2, Model-3, and Model-4 are new complex spatial structure. The cantilever section is subject to the thrust of sliding body soil, and the embedded section is constrained by the sliding bed soil. With the increase of landslide thrust, the change and adjustment of structural internal force are affected by sliding body, sliding bed, and structural system itself. In order to study the working performance of the above four antislide models (i.e., the stress characteristics, load transfer mode, and deformation law of the system) during the storage process of oil tank, the method of graded loading at trailing edge of landslide is adopted for numerical simulation. The load of each time is shown in Table 2.

2.3. Physical Model of Antislide Structure. The physical models of four kinds of arch antislide pile walls are established by ANSYS software, as shown in Figure 3(a). The ideal elastic-plastic constitutive model is adopted for sliding bed soil, which obeys the D-P yield criterion. The bending moment of the pile and displacement of pile head in the four models are numerically simulated and comparatively analyzed, and then the reasonable arch antislide structure is selected [30-32]. In these four models, the horizontal constraint is applied at the back of the sliding bed, the vertical constraint is applied at the bottom of the model, and the left and right sides of the model are stabilized by slope self-stabilization. When the ANSYS software is used to establish the model, the pilesoil contact element and parameter settings are shown in Table 3. The physical parameters of sliding bed soil and sandstone with Solid45 unit are selected as shown in Table 4. The reinforcement is dispersively distributed in Solid65 unit of reinforced concrete structure according to reinforcement ratio. BISO model and Mises yield criterion of isotropic strengthening are adopted for the constitutive relation of concrete material, of which Poisson's ratio and tensile strength are 0.2 and $0.4 \mathrm{MPa}$, respectively. Multilinear MISO model of isotropic strengthening is adopted for reinforcement, of which Poisson's ratio and elastic modulus are 0.18 and $200 \mathrm{MPa}$, respectively. According to different loading conditions, the typical joint stresses of pile body and cap beam are calculated numerically, and then the corresponding bending moment is calculated with APDL language programming.

\section{Numerical Analysis of Different Arch Antislide Structural Systems}

The bending moments in $Y$ direction of model piles are extracted every $1.0 \mathrm{~m}$ from the position of $-8 \mathrm{~m}$ to $9 \mathrm{~m}$ along the $Z$ direction, which are shown in Figures $4 \sim 7$ under different loads. Herein, because the models are all symmetrical structure, six piles on one side are selected for analysis. It can be seen from Figure 4 to 7 that the bending moment of different model piles at the sliding belt is the largest, which decrease rapidly toward both ends. And the bending moment of the whole pile body is distributed in a nearly triangular shape.

Figure 4 shows the bending moments of the traditional antislide structure (Model-1) under different loads. The position of the largest bending moment of the pile is about $1.0 \mathrm{~m}$ below sliding belt, and there is no negative bending moment in these piles. Moreover, the bending moments of the piles P4, P5, and P6 in the landslide middle are larger than those of the piles P1, P2, and P3 on the side of the landslide. Because the uneven landslide thrust cannot be transmitted among the piles, the distribution of bending moment makes the piles in the middle of the system destroy first (pile P6, the bending moment of pile has exceeded the control bending moment at the 5th loading; that is, the pile is destroyed), and then the adjacent piles are damaged gradually (piles P4 and P5 are destroyed at the 7th loading).

Figure 5 shows the bending moments of arch antislide pilewall structure system (Model-2) under different loads. Compared with the traditional antislide structure (Model-1), the negative bending moment occurs within a certain length of pile top in arch antislide pile-wall structure system (Model-2). Under different loads, the negative bending moment of pile P6 top is the largest; then it gradually decreases to both sides of landslide, that is, $\mathrm{P} 5$ and $\mathrm{P} 7, \mathrm{P} 4$ and $\mathrm{P} 8, \mathrm{P} 3$ and $\mathrm{P} 9$, and $\mathrm{P} 2$ and $\mathrm{P} 10$. The sequence of the negative moment appearance and its length range of the pile conform to the above rules. The sum of all negative bending moments at the interface between pile and cap beam is related to the inhomogeneous degree of landslide thrust in the antislide structure system. The more serious the inhomogeneous degree of landslide thrust is, the greater the total negative bending moment of pile top is. According to the bending moment superposition principle [33], the negative bending moment at the pile top is beneficial to reduce the bending moment of model piles with larger thrust in the system and transfer it to the pile with less thrust on both sides, which makes the bending moment of piles on both sides increase. The absolute value of bending moment reduction of some piles is the same as the increment of other piles; that is, the occurrence of negative bending moment will not reduce the total bending moment of the system. The appearance of negative bending moment changes the stress state of model pile, which makes key position of bending moment action further closer to the sliding belt. Compared with the traditional antislide structure (Model-1), the bending moment of pile P6 

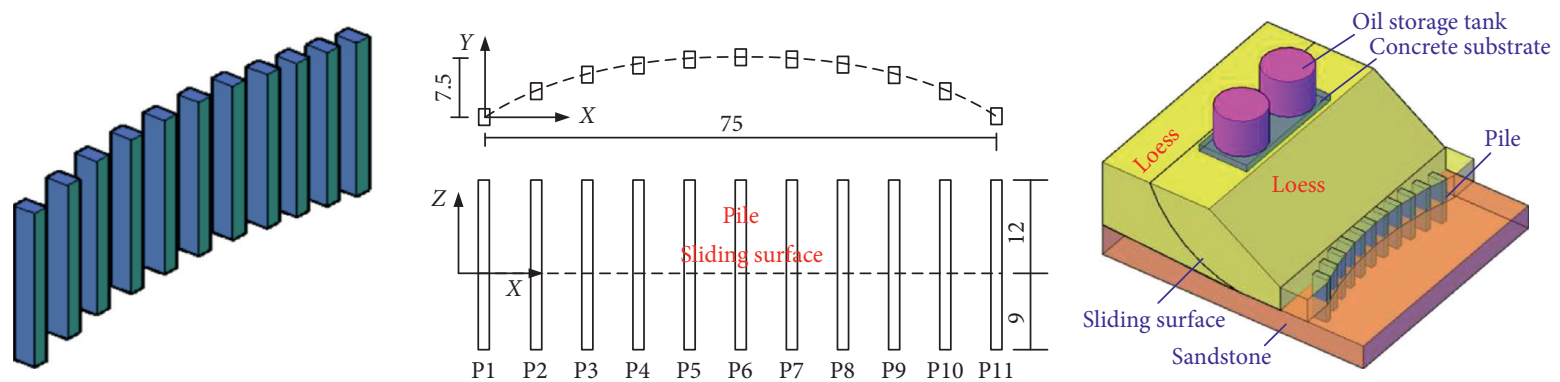

(a)
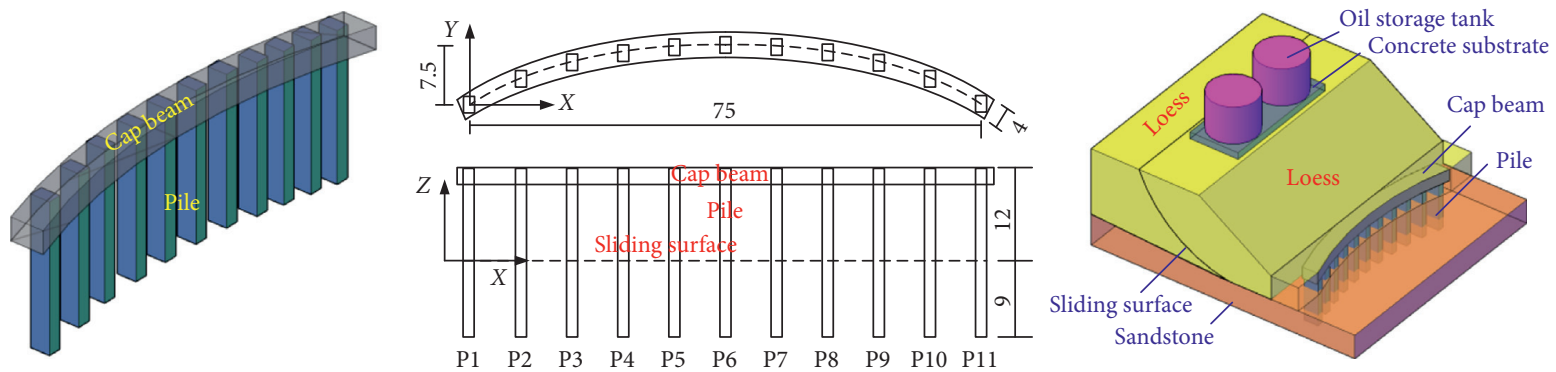

(b)
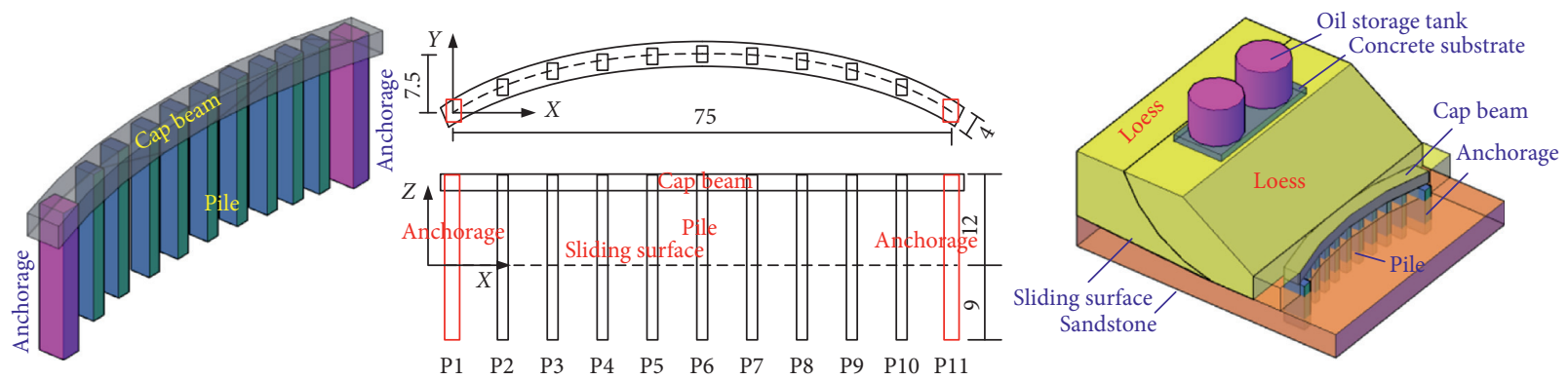

(c)
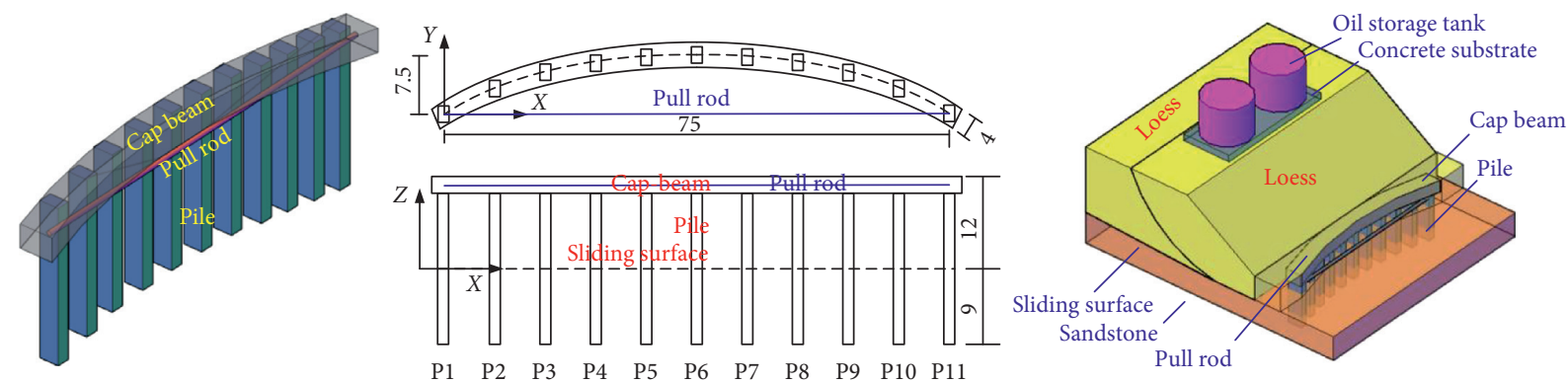

(d)

Figure 2: Physical model of arch antislide structure. (a) Model-1. (b) Model-2. (c) Model-3. (d) Model-4. (1) The models are symmetric structure; (2) Unit m; (3) The pile number are P1, P2, P3 . .P10, P11 respectively from left to right. (4) Central coordinates of pile P1 P6 are $(0,0),(7.5,2.73),(15,4.85),(22.5,6.32),(30,7.2),(37.5,7.5)$.

TABLE 2: Load of each time.

\begin{tabular}{lccccccc}
\hline Load times & 1 & 2 & 3 & 4 & 5 & 6 & 7 \\
\hline Load $/ t$ & 2000 & 4000 & 6000 & 8000 & 10000 & 12000 & 14000 \\
\hline
\end{tabular}

exceeds the control bending moment at the 6th loading, while the bending moment of piles P4 and P5 exceeds the control moment at the 7th loading, which means that arch antislide pile-wall structure system (Model-2) is better than the traditional antislide structure (Model-1).
Figure 6 shows the bending moments of anchorage arch antislide pile-wall structure system (Model-3) under different loads. Compared with arch antislide pile-wall structure system (Model-2), the negative bending moment of the piles in the landslide middle after adding anchorages no longer successively appears with the increase of loading. And with the load increasing, the negative bending moment of piles P2 and P10 increases rapidly and approaches that of pile P6, which is a comprehensive reflection of the 


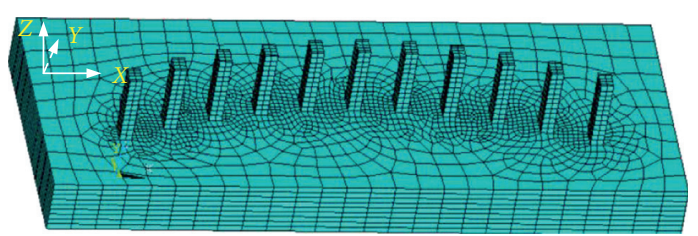

(a)

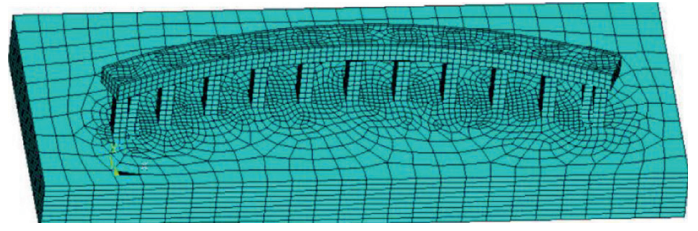

(c)

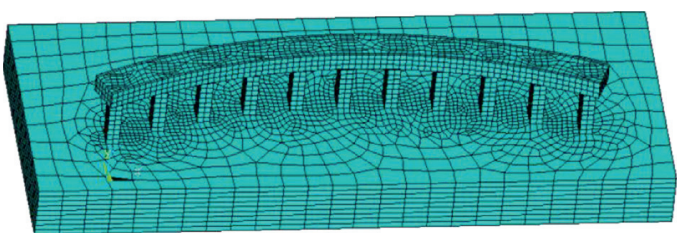

(b)

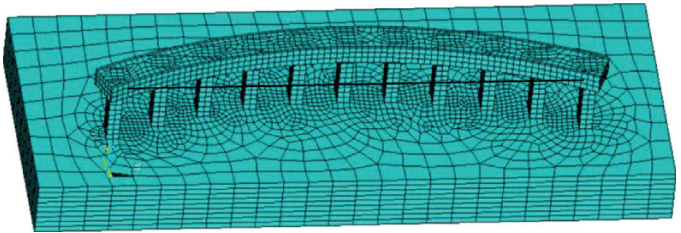

(d)

FIgUre 3: Arch antislide structure system models and grid mesh generation. (a) Model-1. (b) Model-2. (c) Model-3. (d) Model-4.

TABle 3: Pile-soil contact pattern.

\begin{tabular}{lccl}
\hline \multirow{2}{*}{ Pile and soil } & \multicolumn{2}{c}{ Unit type } & Parameter \\
\hline Pile side and soil & CONterface & Target surface & Friction coefficient $=0.30$ KEYOPT,9,0 KEYOPT, 12,2 \\
Pile tip and soil & CONTA171 & TARGE169 & Friction coefficient $=0.30$ KEYOPT,9,0 KEYOPT, 12,2 \\
\hline
\end{tabular}

TABle 4: Physical parameters of landslide.

\begin{tabular}{lcccc}
\hline Parameters & Bulk density $\left(\mathrm{kN} / \mathrm{m}^{3}\right)$ & Poisson's ratio & Internal friction angle $\left({ }^{\circ}\right)$ & Cohesion $(\mathrm{kPa})$ \\
\hline Sliding bed soil & 17.94 & 0.26 & 24 & 88 \\
Sandstone & 24 & 0.22 & 32 & 280 \\
\hline
\end{tabular}
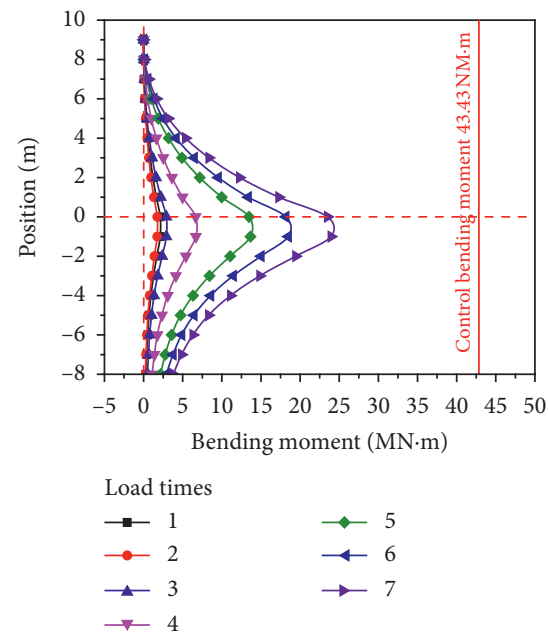

(a)
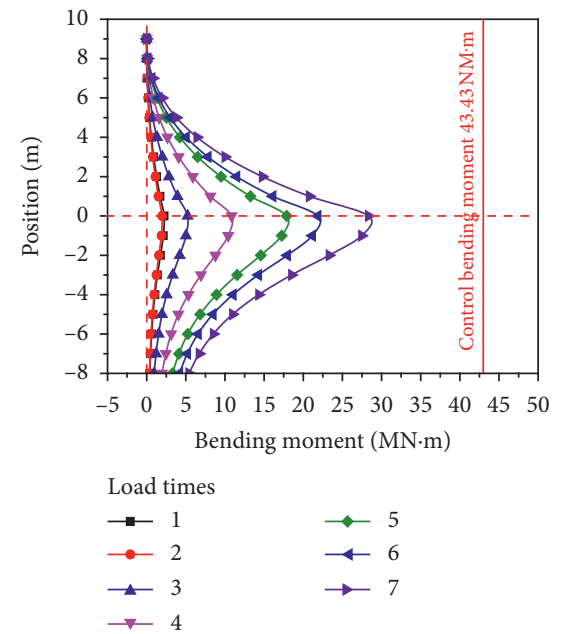

(b)

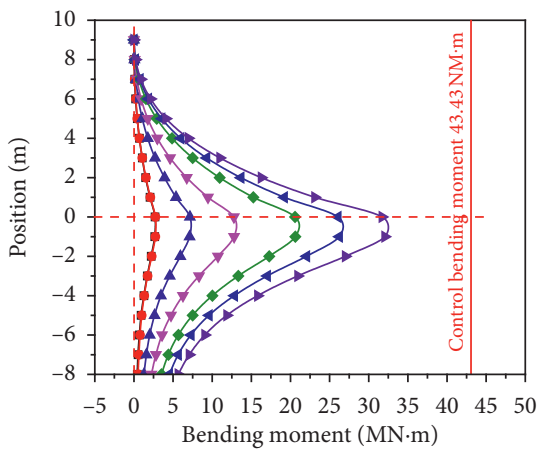

Load times

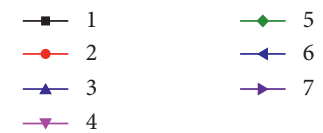

(c)

Figure 4: Continued. 


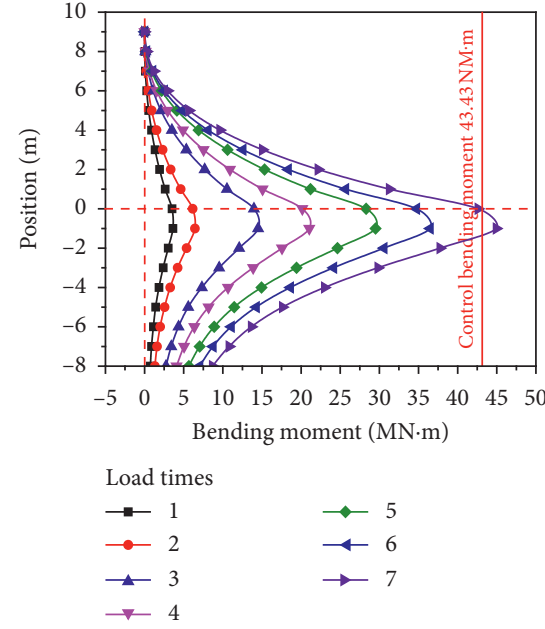

(d)

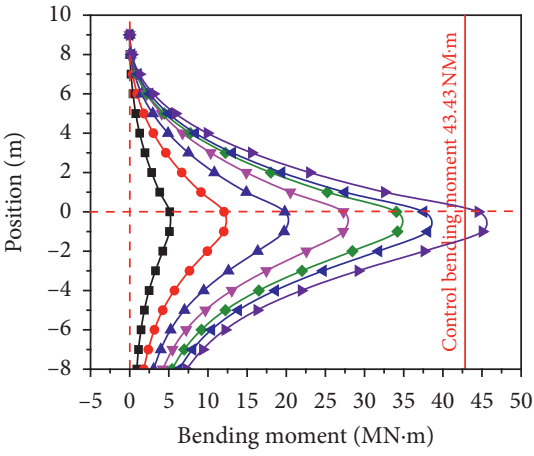

Load times

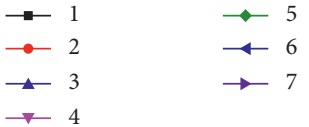

(e)

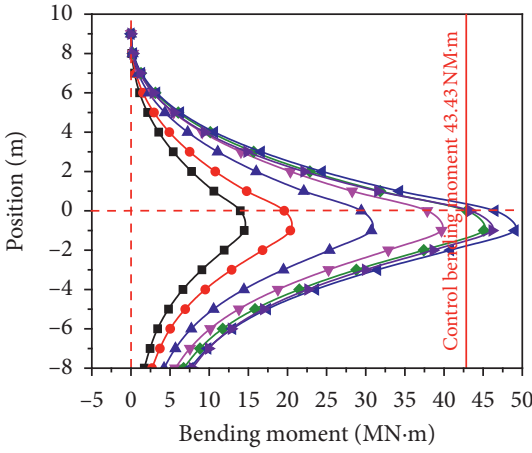

$\begin{array}{ll}\text { Load times } & \\ -1 & \rightarrow-5 \\ \rightarrow 2 & \multimap 6 \\ \longleftarrow 3 & \rightarrow-7 \\ \square 4 & \end{array}$

(f)

Figure 4: Bending moments of antislide structural piles of Model-1 in $Y$ direction. (a) Pile number of P1. (b) Pile number of P2. (c) Pile number of P3. (d) Pile number of P4. (e) Pile number of P5. (f) Pile number of P6.
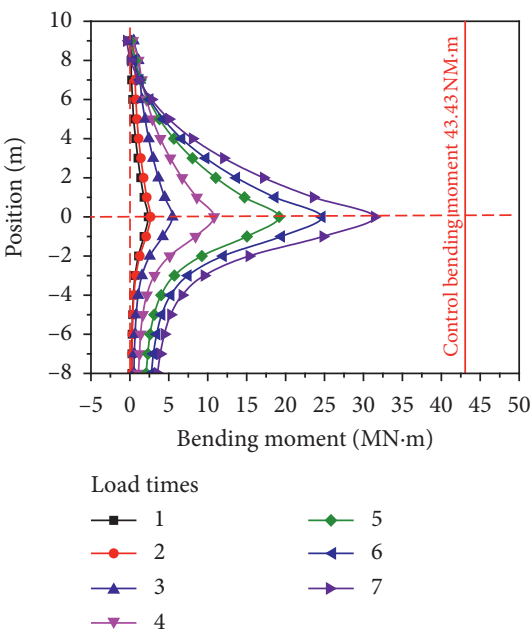

(a)
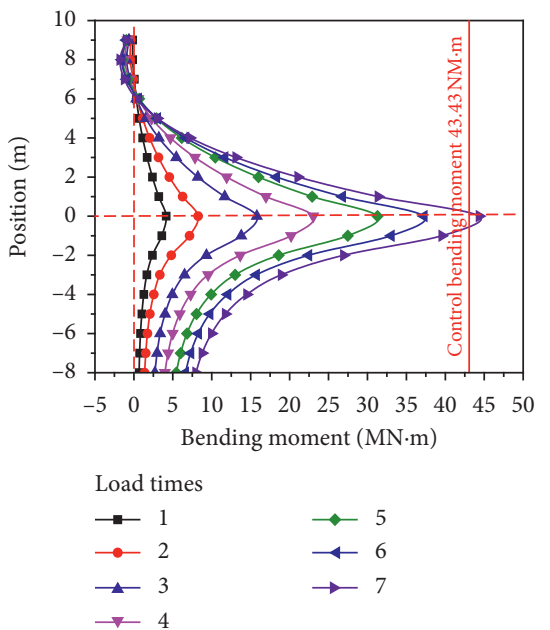

(d)

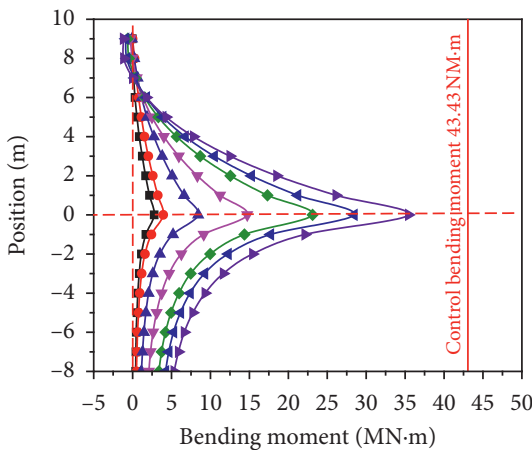

Load times

$\rightarrow-1$
$\because-2$
$\longleftarrow 3$
$\rightarrow-4$

(b)

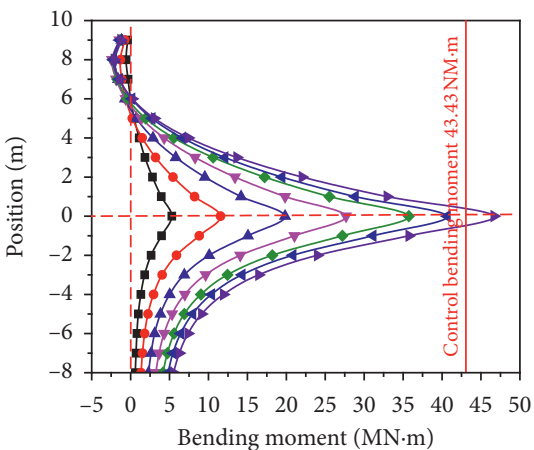

Load times

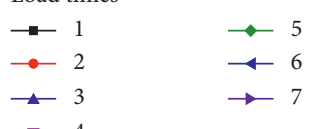

(e)
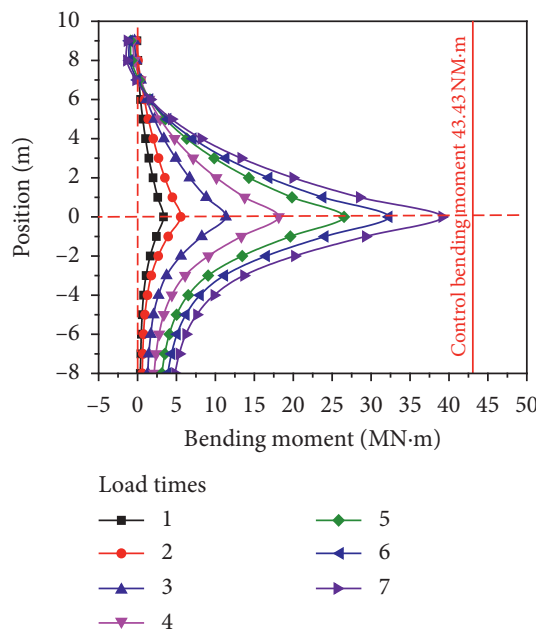

(c)
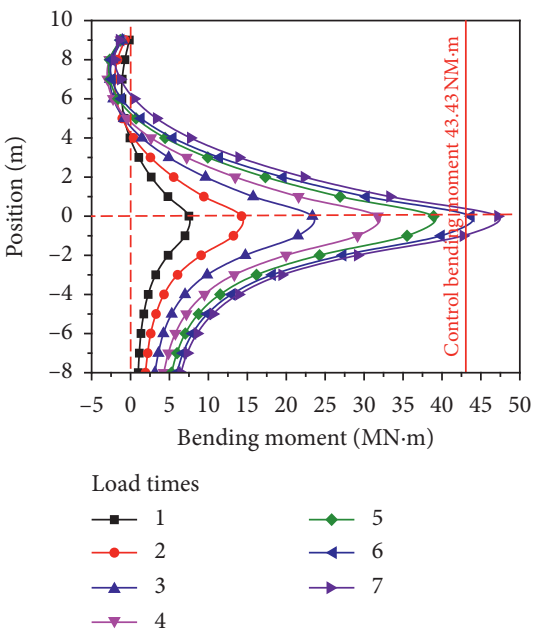

(f)

Figure 5: Bending moments of antislide structural piles of Model-2 in Y direction. (a) Pile number of P1. (b) Pile number of P2. (c) Pile number of P3. (d) Pile number of P4. (e) Pile number of P5. (f) Pile number of P6. 

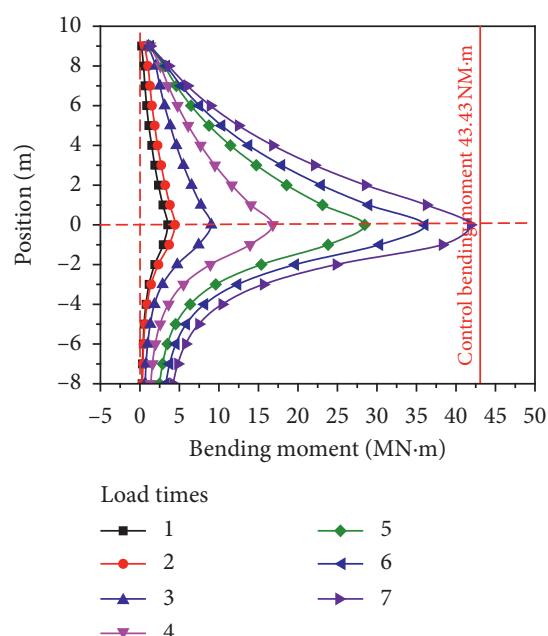

(a)

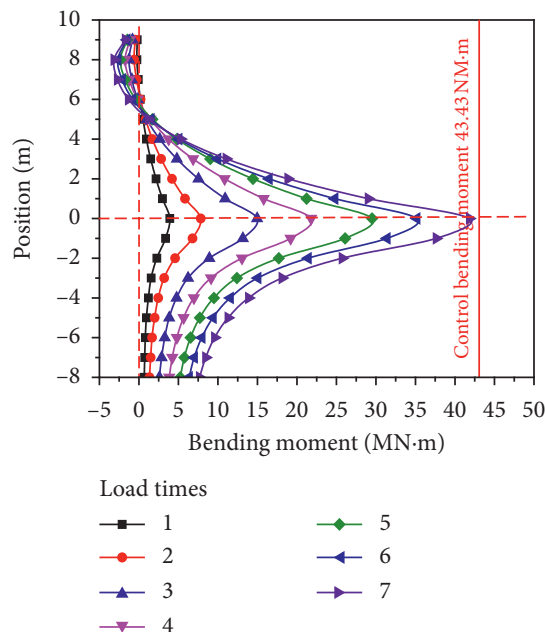

(d)
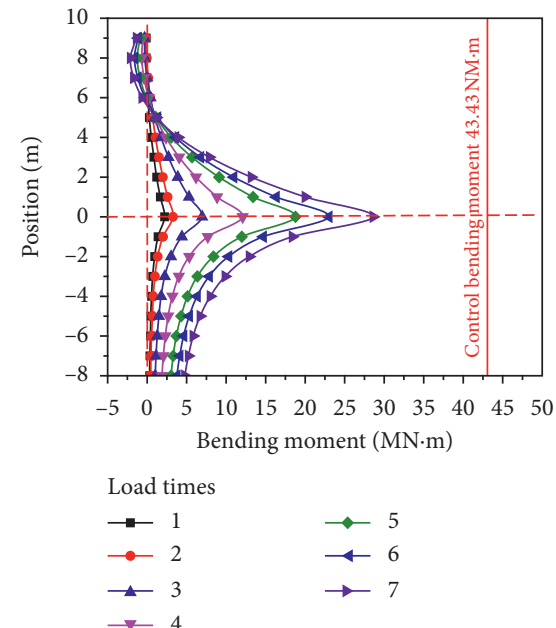

(b)
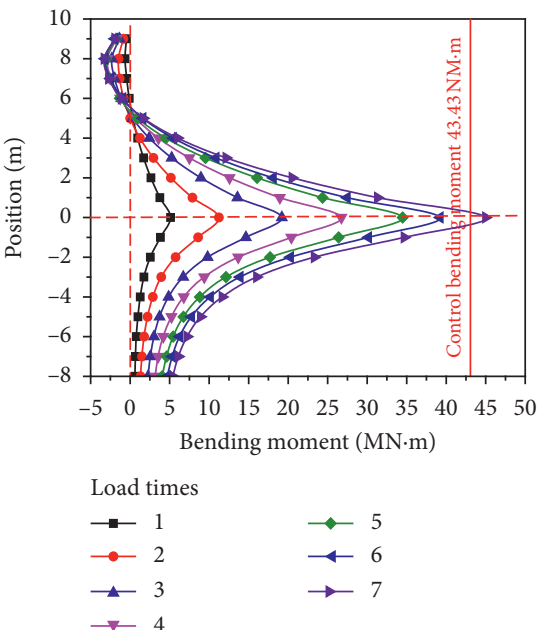

(e)
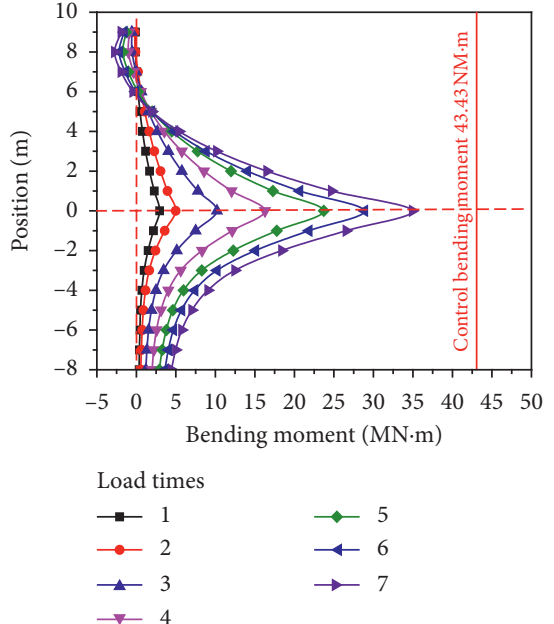

(c)
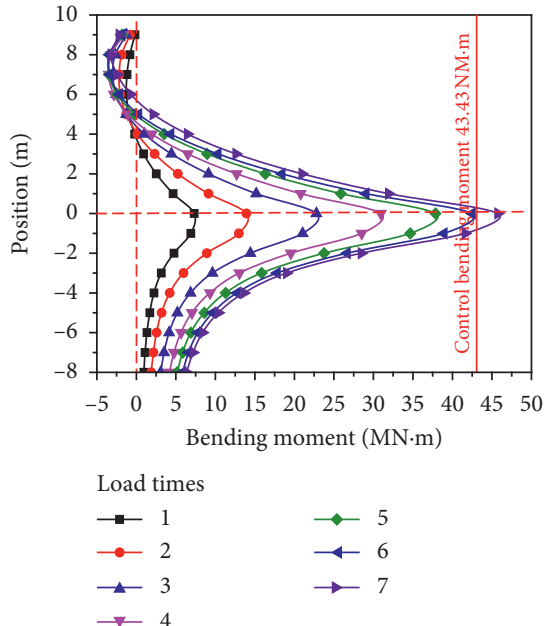

(f)

Figure 6: Bending moments of antislide structural piles of Model-3 in $Y$ direction. (a) Pile number of P1. (b) Pile number of P2. (c) Pile number of P3. (d) Pile number of P4. (e) Pile number of P5. (f) Pile number of P6.

uncoordinated deformation among piles. As the deformation stiffness of piles P1 and P11 is enlarged, the incoordinate deformation between P1 and P2 and P11 and P10 is clearly highlighted. The larger negative bending moment changes the stress state of the model pile, which makes the key position of bending moment action in the middle pile further closer to the sliding belt, and so are piles P1 and P11, and that makes the distribution of the bending moment closer to a triangle shape. Compared with arch antislide pile-wall structure system (Model-2), the bending moment of pile P6 in anchorage arch antislide pile-wall structure system (Model-3) only exceeds the control bending moment at the 7th loading, and so is pile P5, and the bending moment of pile P4 is still within the control bending moment. Therefore, anchorage arch antislide pile-wall structure system (Model-3) is better than arch antislide pilewall structure system (Model-2).

Figure 7 shows the bending moments of pull-rod arch antislide pile-wall structure system (Model-3) under different loads. Compared with arch antislide pile-wall structure system (Model-2) and anchorage arch antislide pile-wall structure system (Model-3), after adding the pull rod, all the piles including piles $\mathrm{P} 1$ and $\mathrm{P} 11$ have the negative bending moment, which increases with the increase of loading. This phenomenon is not caused by the uncoordinated deformation among piles in $Y$ direction. The reason is that each pile has a forward rotation angle as each pile is stressed, while cap beam with the enhancement of deformation stiffness can effectively limit the rotation trend [33]. As a result, the negative bending moment occurs in the upper part of the pile, which is beneficial to reduce the bending moment of each pile; however, it also puts forward the requirements for reinforcement on the backside of each pile [34]. Compared with arch antislide pile-wall structure system (Model-2) and anchorage arch antislide pile-wall structure system (Model-3), the bending moment of pile P6 in pull-rod arch antislide pile-wall structure system (Model4) only exceeds the control bending moment at the 7th loading, and so is pile $\mathrm{P} 5$, and the bending moment of pile $\mathrm{P} 4$ is still within the control bending moment. Therefore, pullrod arch antislide pile-wall structure system (Model-4) is 


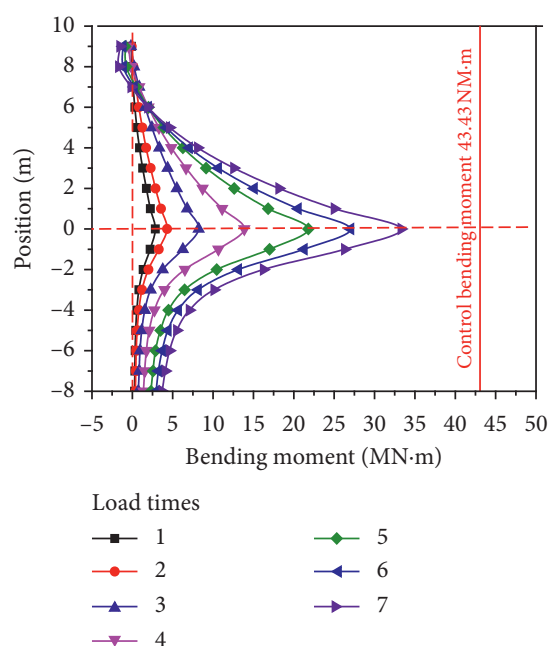

(a)
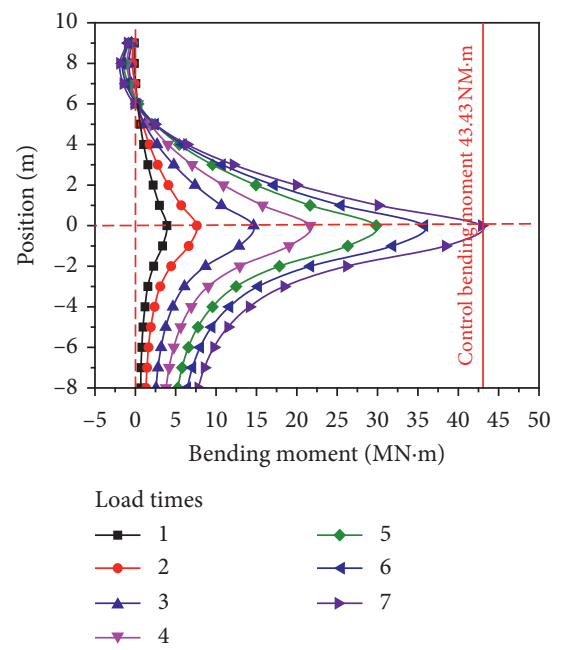

(d)

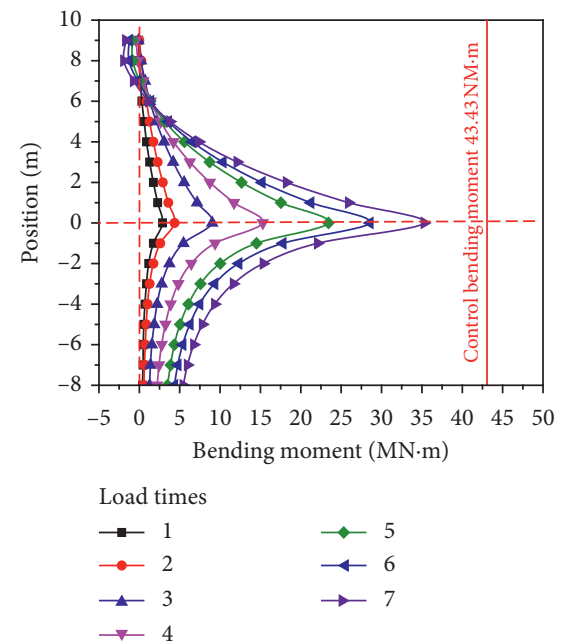

(b)
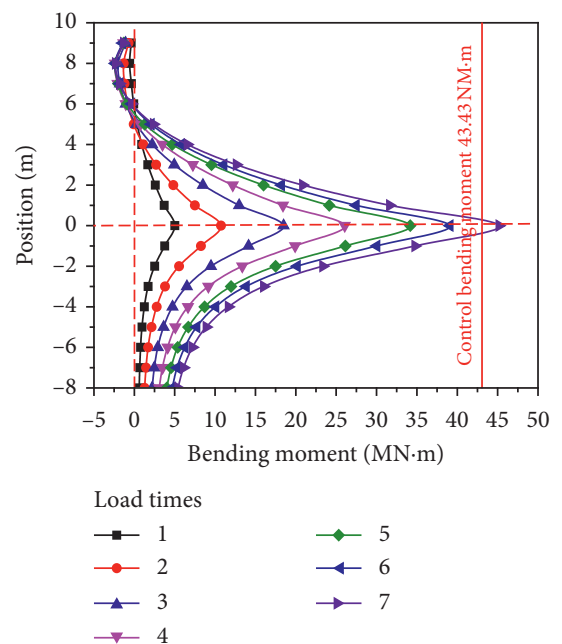

(e)
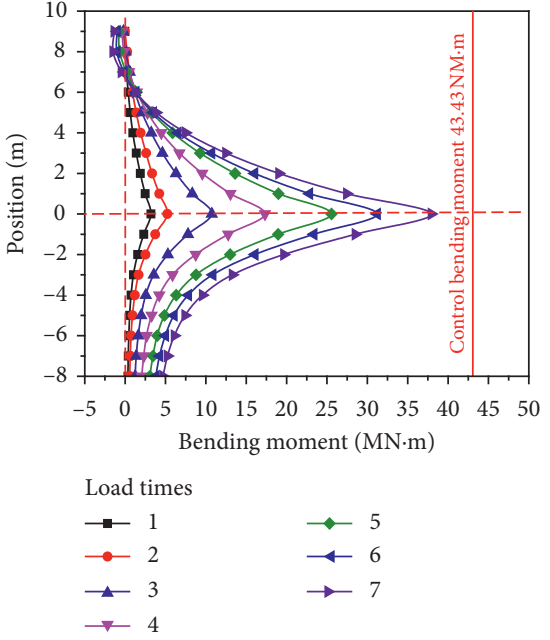

(c)
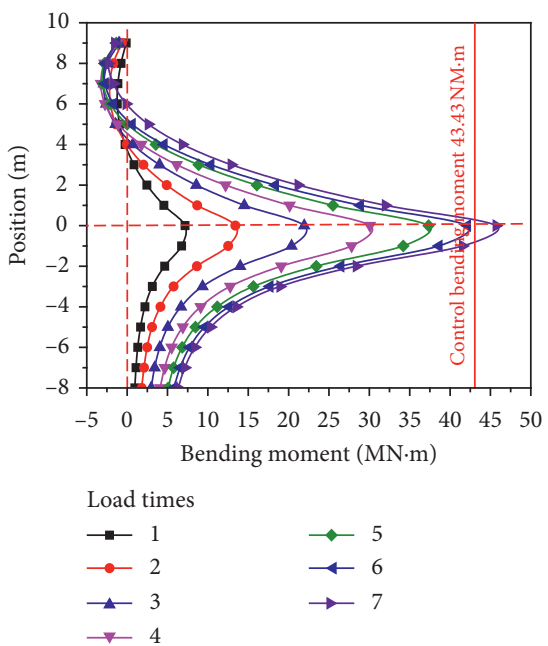

(f)

Figure 7: Bending moments of antislide structural piles of Model-4 in $Y$ direction. (a) Pile number of P1. (b) Pile number of P2. (c) Pile number of P3. (d) Pile number of P4. (e) Pile number of P5. (f) Pile number of P6.

better than arch antislide pile-wall structure system (Model2).

From Figures 4 to 7 , it is found that anchorage arch antislide pile-wall structure system (Model-3) and pull-rod arch antislide pile-wall structure system (Model-4) are better than arch antislide pile-wall structure system (Model-2) and the traditional antislide structure (Model-1).

Figure 8 shows the bending moment of each pile at sliding surface of four models with the increase of loading. It can be seen from Figure 8(a) that the traditional antislide structure (Model-1) has no transfer of force and bending moment among the piles, and the bending moment of each pile is a direct reflection of landslide thrust on the pile body. However, arch antislide pile-wall structure system (Model2) can transfer the bending moment generated by the larger thrust in the landslide middle to the piles with less thrust on both sides of the landslide, so that the bending moment of the whole antislide system tends to be uniform (as shown in Figure $8(\mathrm{~b})$ ). In Figure 8(c), when piles $\mathrm{P} 1$ and P11 are enlarged into anchorages, their bending moments increase significantly. The closer the pile is to the anchorage, the larger the reduction of bending moment is, and the farther away from the anchorage the pile is, the smaller the reduction of moment decreases. This change results in the increase of the bending moment difference between pile P6 and another pile (except P1 and P6), and the difference tends to increase with the increase of loading. This is obviously not in line with the principle of "joint operation" of all the piles in arch antislide system, nor can it give full play to the advantages of high compressive strength of concrete structure cap beam, which will cause the waste of reinforcement of cap beam and the materials of piles P2, P10, P3, and P9. From Figure 8(d), after adding pull rods, the bending moments of piles P1 and P11 increase, while the bending moments of other piles slightly reduce. The total control bending moment of the whole system decreases due to more mobilization of the sliding bed soil effect. 

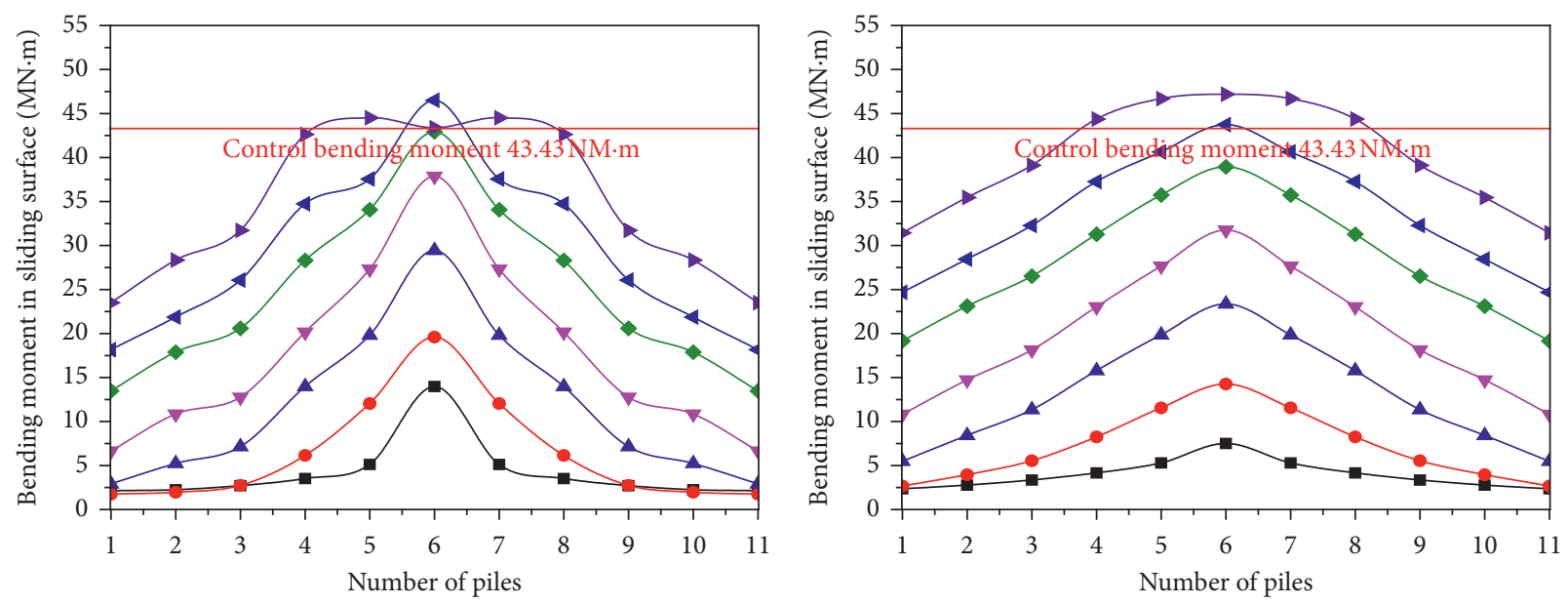

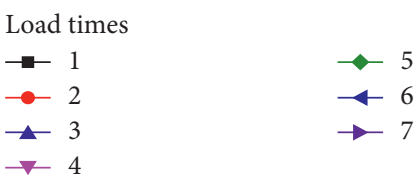

(a)
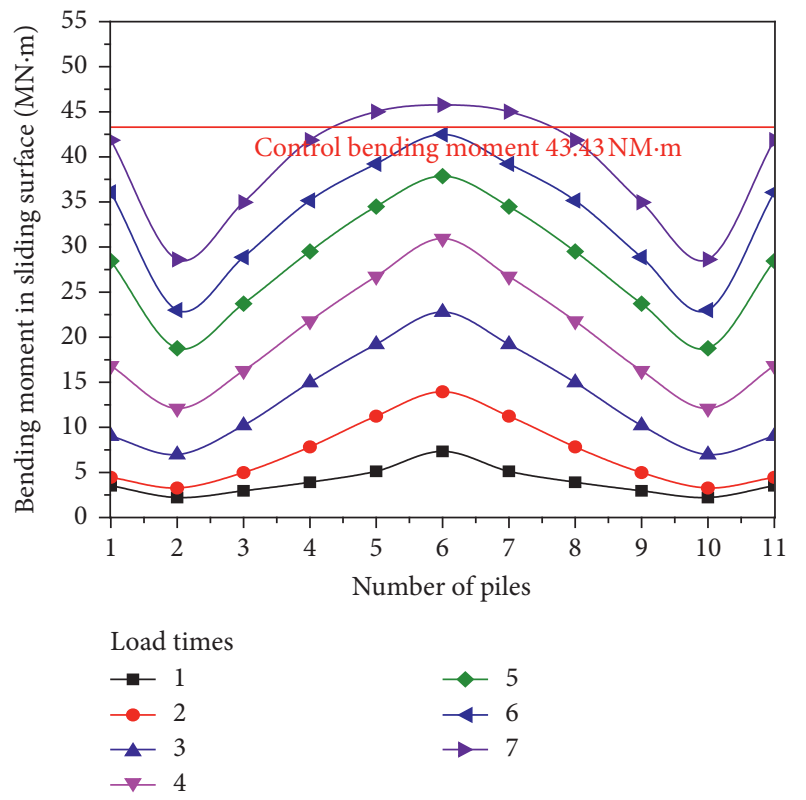

(c)

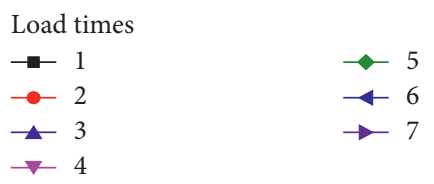

(b)
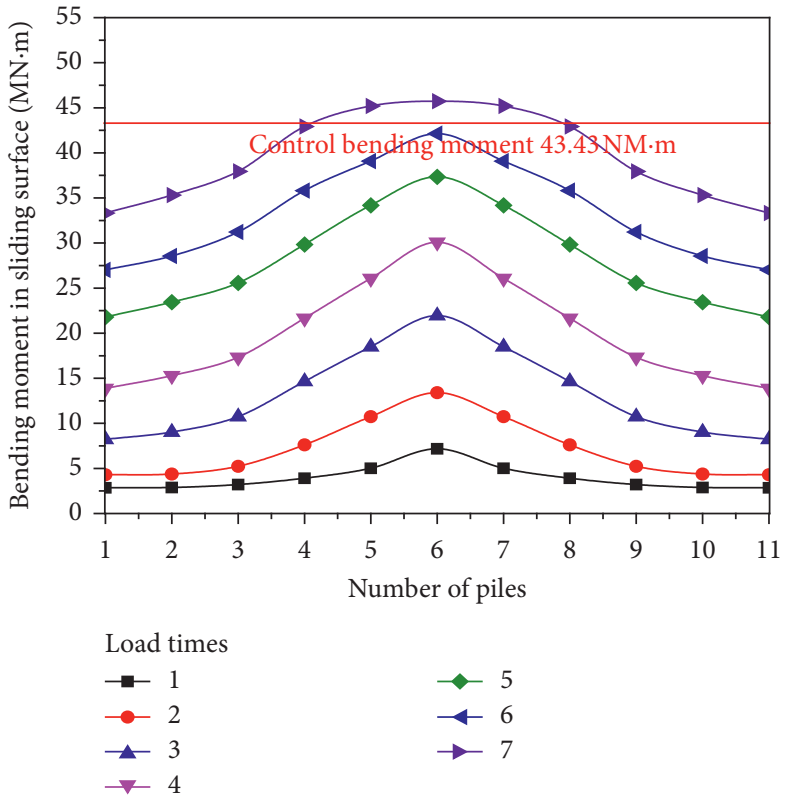

(d)

Figure 8: The bending moment of each pile at $Z=0$ (sliding surface) in different models with different loadings. (a) Model-1. (b) Model-2. (c) Model-3. (d) Model-4.

Figure 9 shows the pile head displacement of four models with different loadings. It can be seen from Figure 9 that the pile head displacement of each pile in different models increases with the increase of loading, and the displacement of middle pile (P6) is the largest. Here, in the traditional antislide structure (Model-1, in Figure 9(a)), there is no constraint and coordination effect of cap beam on the stress and deformation of each pile; the deformation disharmony among the piles is significant; that is, it is "individual combat" of all the piles, which leads to obvious displacement of pile head in the landslide middle; and the displacement of pile head on both sides also increases significantly with the increase of loading. However, when cap beam is adopted in the antislide structure (in Model-2, Model-3. and Model-4), cap beam has a certain restraint and coordination effect on the uneven force and deformation of each pile, and the pile head displacement decreases significantly (as shown in Figures 9(b)-9(d)) with the increase of loading. The pile head displacement is closely related to the pile position in the antislide system, and the displacement of pile head in the landslide middle in the system is always greater than that of the pile in other positions. In summary, from Figures 9(b) to 9(d), the 


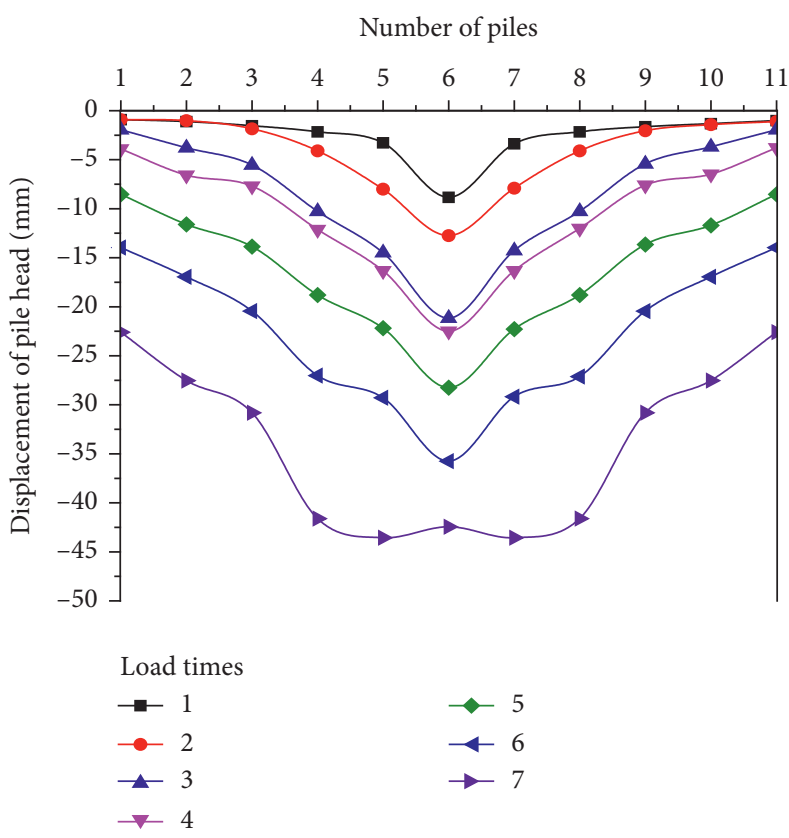

(a)

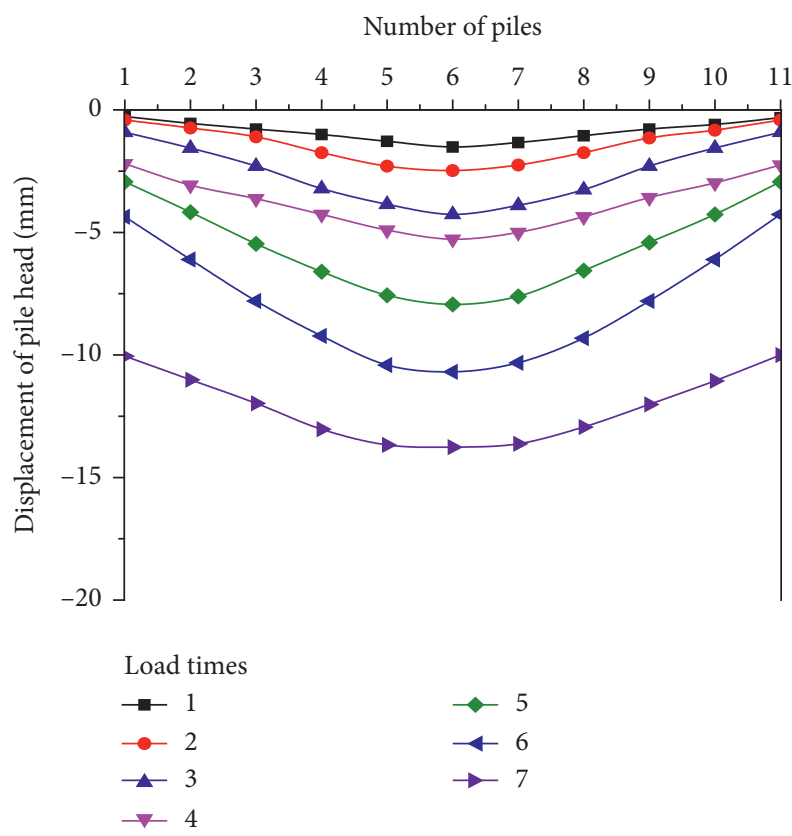

(c)

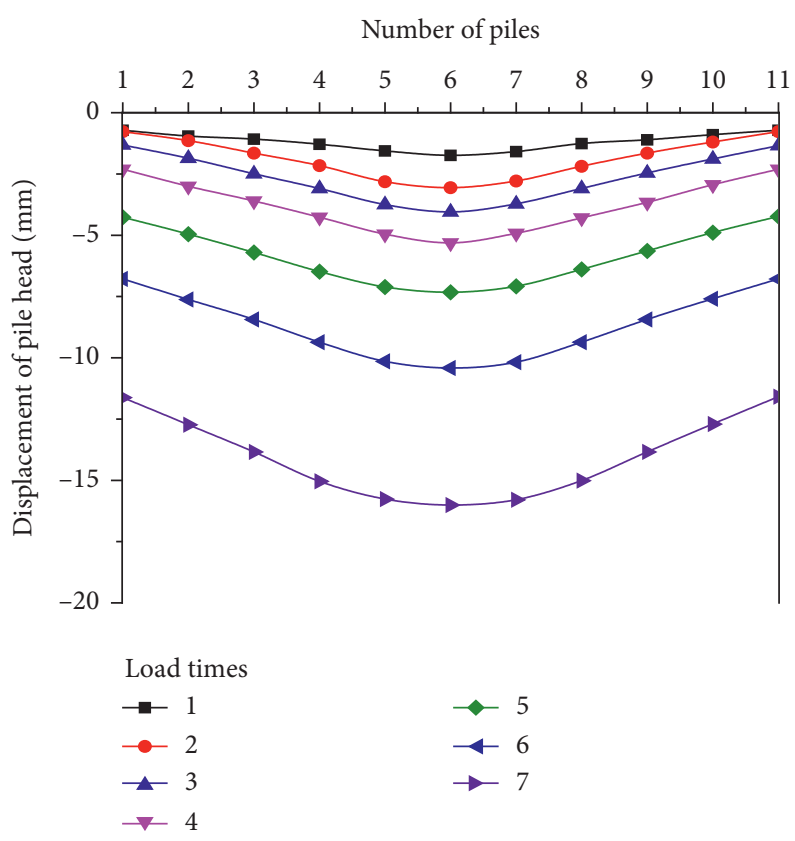

(b)

Number of piles

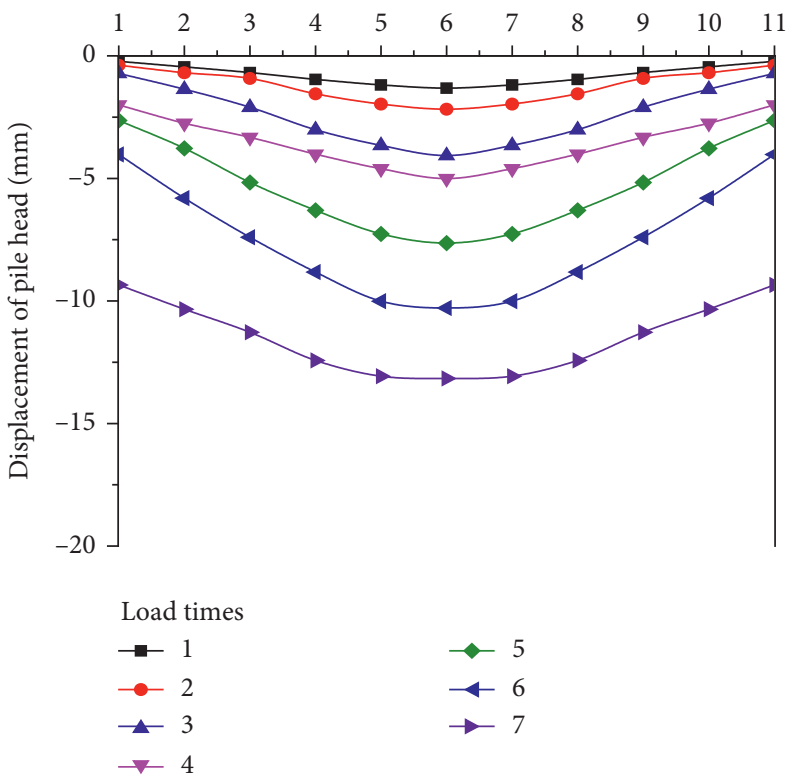

(d)

Figure 9: Displacement variation law of each pile head with different loadings. (a) Model-1. (b) Model-2. (c) Model-3. (d) Model-4.

displacement of each pile head in Model-3 is slightly smaller than that in Model-2, which may be the reason for the insufficient rigidity of cap beam. However, the displacement of each pile head in Model-4 is obviously smaller than that in Model-2.

Figure 10 shows the average displacement of pile head of three kinds of arch antislide pile-wall structure system with cap beam (Model-2, Model-3, and Model-4) and the traditional antislide structure (Model-1). It can be seen from Figure 10(a) that the uncoordinated deformation of the pile and cap beam gives rise to their mutual constraint in arch antislide pile-wall structure system, which causes the average pile head displacements in Model-2, Model-3, and Model-4 to be significantly smaller than that in Model-1. However, the reduction degree of the average pile head displacement is not a fixed value but is related to the loading. The ratio of pile head displacement between arch antislide pile-wall structure systems (Model-2, Model-3, and Model-4) to that of traditional antislide structure (Model-1) is shown in Figure 10(b). It can be seen from Figure 10(b) that with the increase of load the ratio decreases rapidly and then tends to be stable. From the 3rd load, the ratios of Model-2 to Model-1, Model-3 to 


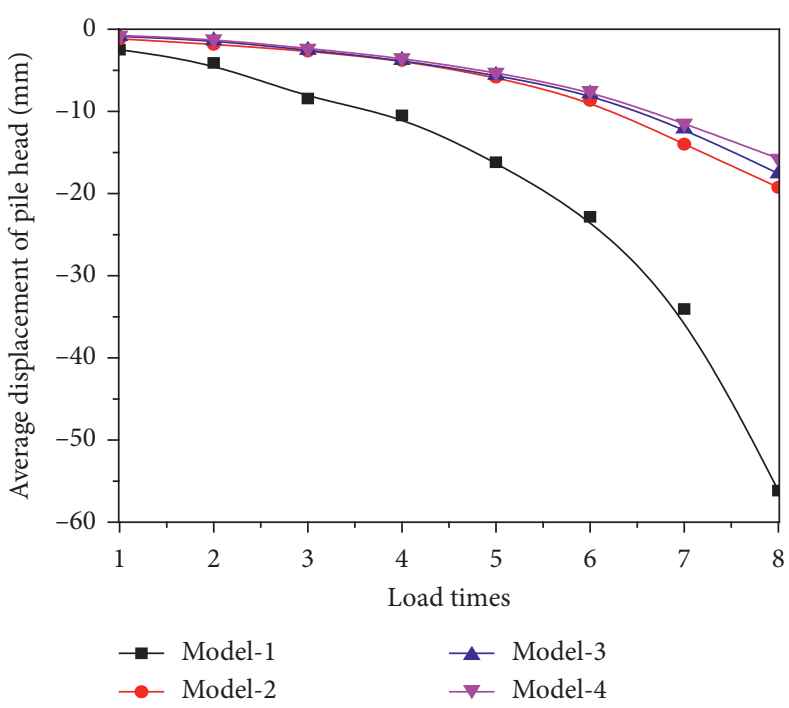

(a)

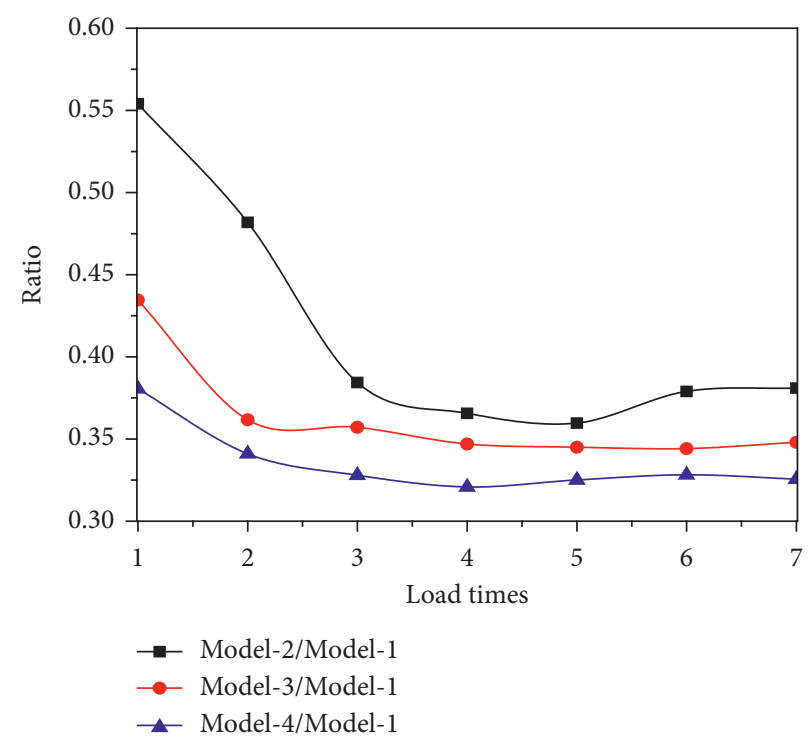

(b)

Figure 10: Average displacement of pile head with different loading. (a) The average displacement of pile head. (b) Comparison of average displacement of pile head.

Model-1, and Model-4 to Model-1 are 37.4\%, 34.6\%, and $32.5 \%$, respectively, and the reduction degree of arch antislide structure system with pull rod is the most significant.

\section{Robustness Evaluation of Antisliding Structure}

4.1. Structural Robustness. According to the importance of landslide treatment project and the severity of possible consequences after its structural failure, the traditional safety factor method is adopted to carry out the corresponding engineering classification, which is used to determine the safety factor $(K)$ satisfying the requirement. And the ratio $(R / S)$ of structural resistance $(R)$ to action effects $(S)$ is used to evaluate engineering safety. The longterm engineering practice has proved that this stability analysis method is effective; however, its most obvious shortcoming is without considering the influence of uncertain factors; that is, it does not consider the randomness of actual parameters, which will bring unpredictable error to the safety evaluation of landslide treatment structure based on safety factor [35, 36]. Therefore, structural reliability with fully considering the uncertainty of various parameters is developed to evaluate the probability of completing the scheduled function. According to the required function of engineering structure, the relevant factors affecting the structural reliability are taken as the basic variables $X_{1}, X_{2}, \ldots, X_{\mathrm{n}}$, which form the function of the structural performance called the structural reliability $\left(R_{S}\right)$ :

$$
R_{S}=g_{x}\left(X_{1}, X_{2}, \ldots, X_{n}\right)
$$

If the basic variables affecting the structural action are combined with the comprehensive action effect $(S)$ and the basic variables of resistance are combined with the comprehensive resistance $(R)$, the function of structural performance can be expressed as $R_{S}=R-S$. Thus, three possible states of the structure in service are defined as reliability state, failure state, and limit state.

Reliability state:

$$
R_{S}=R-S=g_{x}\left(X_{1}, X_{2}, \ldots, X_{n}\right)>0
$$

Failure state:

$$
R_{S}=R-S=g_{x}\left(X_{1}, X_{2}, \ldots, X_{n}\right)<0 .
$$

Limit state:

$$
R_{S}=R-S=g_{x}\left(X_{1}, X_{2}, \ldots, X_{n}\right)=0 .
$$

Assuming that the structural reliability $\left(R_{S}\right)$ obeys normal distribution, the average value is $\mu_{z}$, and the standard deviation is $\sigma_{z}$, then the structural failure probability $\left(P_{f}\right)$ is as follows:

$$
P_{f}=\int_{-\infty}^{0} \frac{1}{\sqrt{2 \pi} \sigma_{z}} \exp \left[-\frac{\left(R_{S}-\mu_{z}\right)^{2}}{2 \sigma_{z}^{2}}\right] \mathrm{d} R_{S} .
$$

Herein, the structural reliability index $(\beta)$ is defined as $\beta=\mu_{z} / \sigma_{z}$, and then the structural reliability probability $\left(P_{s}\right)$ is expressed as

$$
\begin{aligned}
& P_{s}=1-P_{f}=1-\Phi(-\beta)=\Phi(\beta), \\
& P_{f}=\Phi(-\beta),
\end{aligned}
$$

where $\Phi(\cdot)$ is the probability density function of standard normal distribution. And the structural reliability index $(\beta)$ is a positive correlation with the structural reliability 
probability $\left(P_{s}\right)$ and a negative correlation with the structural failure probability $\left(P_{f}\right)$. In practice, it is relatively convenient to obtain the structural reliability index $(\beta)$, which is often used as an indirect index of structural reliability.

Thus, both the structural safety factor $(K)$ and the structural reliability index $(\beta)$ reflect the relationship between the action effect $(S)$ and the structural resistance $(R)$, which are the signs of the ability of the structure to perform the preset work. At present, the design of antislide structure is carried out based on the structural safety factor method, and sometimes, it is combined with the structural reliability index [37]. However, some scholars point out that the influence of parameter uncertainty will make several stochastic models with the same safety factor $(K)$ have different structural reliability index $(\beta)$, and the smaller the parameter discreteness, the larger the structural reliability index $(\beta)$ [38].

For the antislide structure, it is hard to change the fact as a random model which is determined by the uncertainty of the parameters such as slippery surface morphology, sliding belt property, groundwater distribution, and slope external shape. In order to study and compare the adaptability and adjustment ability of different antislide structures to parameter uncertainty, in this paper, the concept of "structural robustness" is introduced to describe the adaptability and adjustment ability of structures to parameter randomness, and its magnitude is expressed by the structural robust degrees $\left(D_{S}\right)$, which is related to the structural reliability $\left(R_{S}\right)$, the default of structural reliability index $\left(\beta_{t}\right)$, the structural working environment $\left[g\left(\left(\mu_{z}, \sigma_{z}\right), S_{t}\right)\right]$, and the condition of the structure itself $\left(S_{t}\right)$ :

$$
D_{S}=f\left(R_{S}, \beta_{t}, g\left(\left(\mu_{z}, \sigma_{z}\right), S_{t}\right)\right), K,
$$

where $R_{S}$ is the structural reliability, which obeys normal distribution and satisfies that the structure is in a safe state $\left(R_{S}>0\right) . \beta_{t}$ is the default of structural reliability index; that is, the comparison of the structural robust degrees $\left(D_{S}\right)$ should be conducted among different structures with the same reliability index or the same structure with different reliability indexes. $g\left(\left(\mu_{z}, \sigma_{z}\right), S_{t}\right)$ is the combination of the function and structural performance; that is, the comparison of the structural robust degrees $\left(D_{S}\right)$ should be conducted in the same working environment. $K$ is the structural safety factor.

When two structures are in the same working environment and have the default of structural reliability index $\left(\beta_{t}\right)$, the reciprocal $(1 / K)$ of structural safety factor $(K)$ becomes the only index of structural robustness, and it can be expressed as

$$
D_{S}=\frac{1}{K}
$$

4.2. Comparative Analysis on Structural Robust Degrees of Four Models. Due to pile P1 and P11 enlarging into anchorages in anchorage arch antislide pile-wall structure system (Model-3), they have different pile section size, reinforcement amount, and material consumption with other antislide structures, which causes its ultimate resistance $(R)$ to be different and its structural reliability is difficult to compare

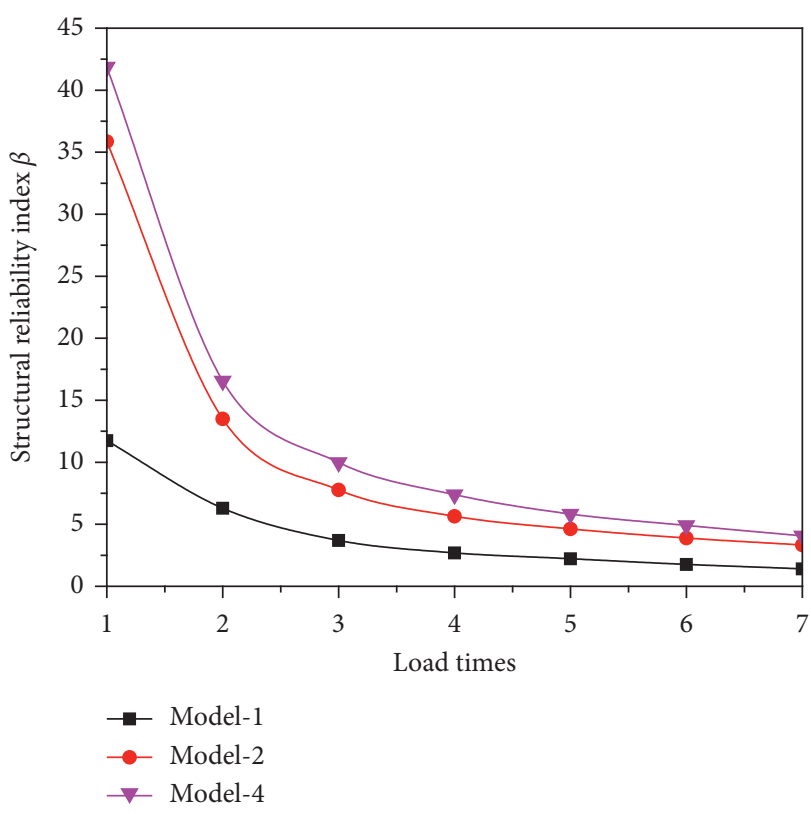

FIgURE 11: Relationship between structural reliability index and loading in different models.

with other models. Moreover, the above analysis has shown that the function of Model-3 is inferior to that of Model-4. Therefore, Model-3 is not considered for the comparison of structural robust degrees in the following analysis.

The other three structural styles, namely, traditional antislide structure (Model-1), arch antislide pile-wall structure system (Model-2), and pull-rod arch antislide pilewall structure system (Model-4), serve the same landslide, and Earth pressure of pile body in different antislide structure models is completely equal, which can be considered that the above four antislide structures have the same working environment. And in each model, the ultimate resistance $(R)$ of each pile is the same because the pile section size, pile material, and reinforcement amount are consistent. Therefore, the three kinds of antislide structure have the same safety factor $(K)$ according to the traditional deterministic model analysis method. However, three kinds of models have different structural robust degrees $\left(D_{S}\right)$, which causes the structural reliability indexes $(\beta)$ to be not equal during the loading process.

The reliability index of pull-rod arch antislide pile-wall structure system (Model-4) is slightly greater than that of arch antislide pile-wall structure system (Model-2). And the reliability indexes of Model-2 and Model-4 are obviously greater than that of the traditional antislide structure (Model-1), as shown in Figure 11.

Taking the 6th loading as an example, the relationship between the structural safety factor and structural reliability index is shown in Figure 12. If the default value of reliability index $\left(\beta_{t}\right)$ is taken as 1.70 (here, the corresponding structural reliability probability is about $95 \%$ ), from the fitting relation, the safety factors $(K)$ are $1.72,1.32$, and 1.23 for traditional antislide structure (Model-1), arch antislide pile-wall structure system (Model-2), and pull-rod arch antislide pilewall structure system (Model-4). The corresponding 


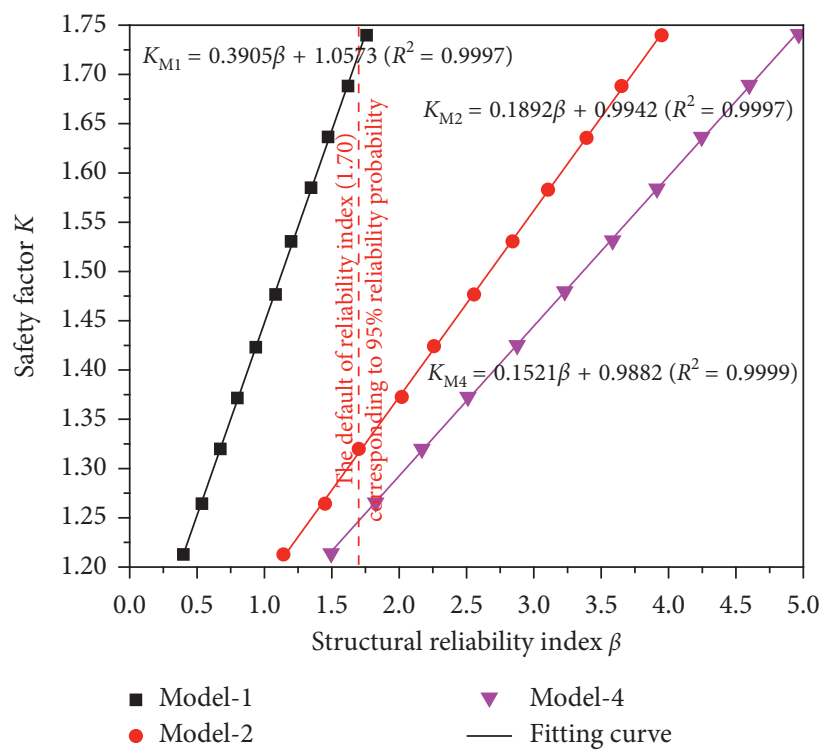

FigURE 12: Relationship between structural reliability index and safety factor in different models.

TABLE 5: The relationship between the default of structural reliability index, safety factor, and structural robust degree.

\begin{tabular}{lccc}
\hline Structure type & Default of structural reliability index $\beta_{t}$ & Safety factor $K$ & Structural robust degree $D_{S}$ \\
\hline Model-1 & 1.70 & 1.72 & 0.58 \\
Model-2 & 1.70 & 1.32 & 0.76 \\
Model-4 & 1.70 & 1.23 & 0.81 \\
\hline
\end{tabular}

relationships among the default values of reliability index $\left(\beta_{t}\right)$, the structural safety factor $(K)$, and the structural robust degree $\left(D_{S}\right)$ can be listed in Table 5 . It can be seen from Table 5 for the default of structural reliability index $\left(\beta_{t}=1.70\right)$ that the different adaptability and adjustment ability of four structural models are different from the discreteness of the random parameters. Compared with the traditional antislide structure, the other two structural models with cap beam can better adapt and adjust the unbalanced landslide thrust among the piles; therefore, they have bigger structural robust degrees. And the traditional antislide structure with a smaller structural robust degree must have a larger safety factor $(K)$ to satisfy the same default of structural reliability index $\left(\beta_{t}\right)$.

\section{Conclusion}

Taking a loess landslide treatment as an example, four kinds of antislide structures with a rise-span ratio of $1: 10$ are designed and modeled to numerically analyze their stress characteristics, load transfer mode, and deformation failure law; the following conclusions can be obtained according to the research results.

(1) Compared with traditional antisliding structure, cap beam in arch antislide pile-wall structure system can transfer the bending moment produced by the larger thrust in the landslide middle to the piles with less thrust on both sides, so that the stress and deformation of the whole antislide system tend to be uniform, which makes all the piles "joint operation." The spatial near rigid structure composed of the pile, cap beam, and sliding bed soil increases the overall stiffness and bending capacity of the antislide structure, which effectively reduce the displacement of pile head. The arch antislide pile-wall structure system has the ability to adjust the internal force of each part of the structure to adapt to the fuzzy and changeable slope problems.

(2) After piles P1 and P11 enlarged into anchorages, arch antislide pile-wall structure system (Model-2) is transformed into anchorage arch antislide pile-wall structure system (Model-3). The bending moments of anchorage P1 and P11 increase significantly; however, the bending moments of adjacent piles P2, P3, P10, and P9 decrease obviously, and the control moments of piles P5, P6, and P7 located in the landslide middle have little change. As a result, the difference of the bending moment between side piles $\mathrm{P} 2$ and P10 and middle pile P6 becomes larger, which does not conform to the principle of "joint operation" of piles.

(3) After adding a pull rod between piles P1 and P11, arch antislide pile-wall structure system (Model-2) is transformed into pull-rod arch antislide pile-wall structure system (Model-4). This structure limits the displacement of cap beam in $X$ direction and 
enhances the restraint capacity to the incompatible stress and deformation of each pile. The control moment of each pile in the system is more balanced, and the sliding bed soil is more involved in the antislide system.

(4) According to the analysis of pile bending moment with different loading, it is found that Model-3 and Model- 4 are better than Model- 2 and Model-1. And the average displacements of pile head of Model-2 and Model-3 and Model-4 are about 37.4\%, 34.6\%, and $32.5 \%$ of Model-1. Obviously, the degree of reduction of arch antislide structure system with pull rod is the most significant.

(5) Structural robust degree is used to evaluate the adaptability and adjustment ability of the structure to the randomness of parameters. Model-2 and Model-4 can better adapt and adjust the unbalanced landslide thrust among the piles, so they have bigger structural robust degrees than that of Model-1. Compared with Model-1, as the failure probability of the same landslide treatment is $5 \%$, the structural robust degrees of Model-2 and Model- 4 improved by $31.03 \%$ and $39.65 \%$, respectively.

\section{Data Availability}

No data were used in this study.

\section{Conflicts of Interest}

The authors declare that they have no conflicts of interest.

\section{Acknowledgments}

This study was financially supported by the National Natural Science Foundation of China (nos. 41977228 and 41702298).

\section{References}

[1] Y. Kong, H. N. Ruan, X. F. Huang, and Z. D. Zhu, "Field testing of earth pressures in a large-scale natural loess slope," KSCE Journal of Civil Engineering, vol. 22, no. 4, pp. 22662273, 2018.

[2] J.-s. Xu and X.-l. Yang, "Effects of seismic force and pore water pressure on three dimensional slope stability in nonhomogeneous and anisotropic soil," KSCE Journal of Civil Engineering, vol. 22, no. 5, pp. 1720-1729, 2018.

[3] H. L. Tian, J. P. Qiao, and X. P. Li, "Analysis of danba landslide," Wuhan University Journal of Natural Sciences, vol. 11, no. 4, pp. 882-886, 2006.

[4] H. Tang, C. Li, X. Hu et al., "Deformation response of the Huangtupo landslide to rainfall and the changing levels of the three gorges reservoir," Bulletin of Engineering Geology and the Environment, vol. 74, no. 3, pp. 933-942, 2015.

[5] X. Y. Zhao, K. P. Li, and D. Xiao, "A simplified method to analyze the load on composite retaining structures based on a novel soil arch model," Bulletin of Engineering Geology and the Environment, vol. 79, pp. 1-2, 2020.

[6] Y.-p. Zeng, "Analysis on the stability characteristics of rock and soil anti-sliding in unsaturated soft base embankment,"
Geotechnical and Geological Engineering, vol. 37, no. 5, pp. 4565-4574, 2019.

[7] L. Q. Ma, K. Yang, W. Z. Yuan et al., "Centrifuge modeling of the pile foundation reinforcement on slopes subjected to uneven settlement," Bulletin of Engineering Geology and the Environment, vol. 79, pp. 1-12, 2020.

[8] S. Li, H. Gao, D. Xu, and F. Meng, "Comprehensive determination of reinforcement parameters for high cut slope based on intelligent optimization and numerical analysis," Journal of Earth Science, vol. 23, no. 2, pp. 233-242, 2012.

[9] T. F. Hu and T. L. Wang, "Numerical investigation of the performance of a new anchored micropile structure against landslides," Soil Mech Found Eng, vol. 56, no. 1, pp. 321-327, 2019.

[10] R. Cojean and Y. J. Caï, "Analysis and modeling of slope stability in the three-gorges dam reservoir (China) - the case of Huangtupo landslide," Journal of Mountain Science, vol. 8, no. 2, pp. 166-175, 2011.

[11] G. X. Wang, "Choice and optimization of landslide control plan," Chinese Journal of Rock Mechanics and Engineering, vol. 25, pp. 3867-3873, 2006.

[12] J.-J. Wang, Y. Liang, H.-P. Zhang, Y. Wu, and X. Lin, “A loess landslide induced by excavation and rainfall," Landslides, vol. 11, no. 1, pp. 141-152, 2014.

[13] S. G. Kushner, "Effect of technogenic factors on slide formation in loess soils," Soil Mechanics and Foundation Engineering, vol. 38, no. 2, pp. 37-41, 2001.

[14] S. I. Matsii and F. N. Derevenets, "Application of finite-element method to investigate interaction between slide-prone soils and piles," Soil Mechanics and Foundation Engineering, vol. 42, no. 4, pp. 120-126, 2005.

[15] S. I. Matsii and F. N. Derevenets, "Interaction between a slideprone soil and piles with consideration of the configuration of the retaining structure," Soil Mechanics and Foundation Engineering, vol. 44, no. 2, pp. 49-55, 2005.

[16] X. Zhang and J. H. Tan, "Research on Majiagou landslide stability analysis and control design," in Proceedings of the 2012 International Conference on Cybernetics and Informatics, pp. 595-602, Hyderabad, India, January 2012.

[17] I. Shooshpasha and H. A. Amirdehi, "Evaluating the stability of slope reinforced with one row of free head piles," Arabian Journal of Geosciences, vol. 8, no. 4, pp. 2131-2141, 2015.

[18] C. Li, X. Liu, Q. Liu, and T. Liu, "Influence of isosceles trapezoid cross-section on the reinforcement effect of stabilizing piles," KSCE Journal of Civil Engineering, vol. 20, no. 7, pp. 2670-2676, 2016.

[19] J. Wu, C. Li, Q. Liu, F. Fan, and F. S. Fan, "Optimal isosceles trapezoid cross section of laterally loaded piles based on friction soil arching," KSCE Journal of Civil Engineering, vol. 21, no. 7, pp. 2655-2664, 2017.

[20] M.-h. Yang, B. Deng, and M.-h. Zhao, "Experimental and theoretical studies of laterally loaded single piles in slopes," Journal of Zhejiang University-Science A, vol. 20, no. 11, pp. 838-851, 2019.

[21] G. Zhang, L. Wang, and Y. Wang, "Pile reinforcement mechanism of soil slopes," Acta Geotechnica, vol. 12, no. 5, pp. 1035-1046, 2017.

[22] C. D. Li, W. Q. Chen, Y. J. Song, W. P. Gong, and Q. H. Zhao, "Optimal location of piles in stabilizing slopes based on a simplified double-row piles model," KSCE Journal of Civil Engineering, vol. 24, no. 2, pp. 1-13, 2020.

[23] C. Zhou, X.-l. Hu, W.-b. Zheng, C. Xu, and Q. Wang, "Displacement characteristic of landslides reinforced with flexible piles: field and physical model test," Journal of Mountain Science, vol. 17, no. 4, pp. 787-800, 2020. 
[24] D. Liu, X. Hu, C. Zhou, L. Li, C. He, and T. Sun, "Model test study of a landslide stabilized with piles and evolutionary stage identification based on thermal infrared temperature analysis," Landslides, vol. 17, no. 6, pp. 1393-1404, 2020.

[25] R. Xue, S. Bie, L. Guo, and P. Zhang, "Stability analysis for cofferdams of pile wall frame structures," KSCE Journal of Civil Engineering, vol. 23, no. 9, pp. 4010-4021, 2019.

[26] S. F. Wang and Y. P. Yin, "Effect of vertical load on shear characteristics of micro-piles in landslide," in Landslide Science for a Safer Geoenvironment, K. Sassa, P. Canuti, and Y. Yin, Eds., pp. 33-37, Springer, Berlin, Germany, 2014.

[27] L. Ma, Y. Hu, D. Gu, and C. Jiang, "Characteristics and application of micropiles in slope engineering," in Proceedings of China-Europe Conference on Geotechnical Engineering," Springer Series in Geomechanics and Geoengineering, W. Wu and HS. Yu, Eds., pp. 1504-1507, Springer, Berlin, Germany, 2018.

[28] N. Li, Y. Men, L. Yuan, H. Gao, J. Li, and B. Wang, "Study on the mechanical characteristic of micropiles supporting landslide under step-loadings," Geotechnical and Geological Engineering, vol. 38, no. 3, pp. 2761-2771, 2020.

[29] L. J. Luo, F. S. Zhao, and A. Z. Wang, "Deformation character of landslide and its supporting structure in area of metamorphic rocks," Journal of Earth Sciences and Environment, vol. 30 , no. 2, pp. 177-182, 2008.

[30] T. L. Anderson, Fracture Mechanics: Fundamentals and Applications, Taylor \& Francis Group, LLC, UK, 2005.

[31] T. Jankowiak and T. Lodygowski, "Dentification of parameters of concrete damage plasticity constitutive model," Foundations of Civil and Environmental Engineering, vol. 6, pp. 53-69, 2005.

[32] T. Zhang, ANSYS APDL Parametric Finite Element Analysis Technology and its Application, China Water Power Press, Beijing, China, 2013.

[33] Y. Q. Long and S. H. Bao, Structural Mechanics, Higher Education Press, Beijing, China, 2000.

[34] A. Q. Li, W. R. Cheng, and T. C. Wang, The Design Theory for Concrete Structure, China Architecture \& Building Press, Beijing, China, 2012.

[35] H. P. Hong and G. Roh, "Reliability evaluation of earth slopes," Journal of Geotechnical and Geoenvironmental Engineering, vol. 134, no. 12, pp. 1700-1705, 2008.

[36] R. W. M. Cheng and W. H. Tang, "Bayesian calibration of slope failure probability," Proceedings of Sessions of GeoDenver 2000-Slope Stability 2000. GSP, vol. 101, pp. 72-85, 2000.

[37] A. H. S. Ang and W. H. Tang, Probability Concepts in Engineering: Emphasis on Applications to Civil and Environmental Engineering, John Wiley \& Sons, Hoboken, NJ, USA, 2006.

[38] C. Cremona, "Probabilistic approach for cable residual strength assessment," Engineering Structures, vol. 25, no. 3, pp. 377-384, 2003. 